\title{
Crustacean Plankton in Lake Winnipeg: Variation in Space and Time as a Function of Lake Morphology, Geology, and Climate
}

\author{
K. Patalas and A. Salki \\ Department of Fisheries and Oceans, Central and Arctic Region, Freshwater Institute, 501 University Crescent, Winnipeg, Man. R3T 2N6, Canada
}

Patalas, K., and A. Salki. 1992. Crustacean plankton in Lake Winnipeg: variation in space and time as a function of lake morphology, geology, and climate. Can. J. Fish. Aquat. Sci. 49: 1035-1059.

\begin{abstract}
Rivers draining different geological basins have the most important impact on the formation of the planktonic community in Lake Winnipeg. Very diverse patterns of distribution of individual species reflected the complexity of the water masses structured by lake morphology and the configuration of river inflows. Of the 34 species identified (15 copepods and 19 cladocerans), 12 were found exclusively in the South Basin, 7 exclusively in the North Basin, and 15 were common to both basins. A "core" group of 12 species was distributed over the whole lake, but the remaining 22 species ("unsuccessful invaders") were present only in restricted areas, mostly adjacent to river inflows. Plankton species composition has not exhibited major changes after $40 \mathrm{yr}$, but abundance has at least doubled, probably due to eutrophication. Several times more planktonic crustaceans were found in the western part of the lake, affected by sedimentary drainage, than in the eastern part, influenced by the Precambrian Shield. The plankton community in a lake as large as Lake Winnipeg can be affected by differences in climate within its shores. Midsummer epilimnion temperature was the single best parameter predicting crustacean abundance in Lake Winnipeg and other North American great lakes and, combined with phosphorus loading, explained $97 \%$ of variance.
\end{abstract}

Les tributaires traversant différents bassins géologiques avant de se déverser dans le lac Winnipeg ont le plus important impact sur la communauté planctonique lacustre. Les régimes de répartition très divers des espèces traduisent la complexité des masses d'eau dont la structure est déterminée par la morphologie du lac et la configuration des influx fluviaux. Des 34 espèces de plancton identifiées (soit 15 espèces de copépodes et 19 espèces de cladocères), 12 espèces n'étaient présentes que dans le bassin méridional, 7 dans le bassin septentrional et 15 étaient communes à ces deux bassins. Un "noyau" de 12 espèces était réparti sur toute la superficie du lac, mais les autres 22 espèces ("des envahisseurs sans succès") n'étaient présentes que dans certains secteurs restreints, en particulier aux environs des influx fluviaux. La variété des espèces planctoniques n'a pas grandement changé au cours des 40 dernières années, mais leur abondance a au moins doublé, probablement en réaction à l'eutrophisation. Ainsi, l'abondance de crustacés planctoniques était plusieurs fois plus élevée dans le secteur occidental du lac qui reçoit des sédiments que le secteur oriental soumis à l'influence du Bouclier canadien. La communauté planctonique d'un lac aussi grand que le lac Winnipeg peut être touchée par des variations du climat local. La température de l'épilimnion au milieu de l'été s'est révélée le meilleur paramètre pour prédire l'abondance des crustacés dans le lac Winnipeg et d'autres grands lacs de l'Amérique du Nord et, ajoutée à la charge en phosphore, expliquait $97 \%$ de sa variance.

Received April 16, 1991

Accepted November 12, 1991

Reçu le 16 avril 1991

(JA996)

Accepté le 12 novembre 1991

G reat lakes are usually complex systems supplied with waters from different geologic areas and even from different climatic regions. It is logical to expect this complexity to influence abundance, distribution, and, perhaps, species composition of their planktonic communities. Small lakes tend to receive water from geologically and climatologically uniform drainage areas.

Lake Winnipeg is an example of a great lake, receiving water from sedimentary areas south and west of the lake via the Red and Saskatchewan rivers, respectively, and from the Precambrian Shield on the east drained mainly by the Winnipeg, Pigeon, Berens, and Poplar rivers. The lake extends between $50^{\circ} 0^{\prime}$ and $53^{\circ} 50^{\prime}$ north latitude and $96^{\circ} 15^{\prime}$ and $99^{\circ} 15^{\prime}$ west longitude, thus covering $3^{\circ} 30^{\prime}$ of latitude and $3^{\circ} 30^{\prime}$ of longitude. Within such a large area, significant climatic differences are observed and the responses of the planktonic community to these differences provide valuable information for predicting future responses of biotic systems to expected global climatic changes.
There is very little information available on the long-term changes of planktonic communities in such a large lake. The rare collections taken in the past have generally limited use for comparison with more recent samples. Bajkov's data from 1929 (Bajkov 1934) provided such a rare opportunity. The main objectives of this study were to (a) determine the species composition of the pelagic crustacean plankton, (b) examine the variation in space and time of zooplanktonic species, (c) compare the present data with historical records, and (d) understand how morphology, geology, and climate control the distribution and abundance of species within Lake Winnipeg.

\section{Methods}

A study of the pelagic crustacean plankton in Lake Winnipeg was carried out during June-October 1969 as part of a collaborative effort to characterize the chemical and biological conditions of the lake. A network of 51 stations was established to 


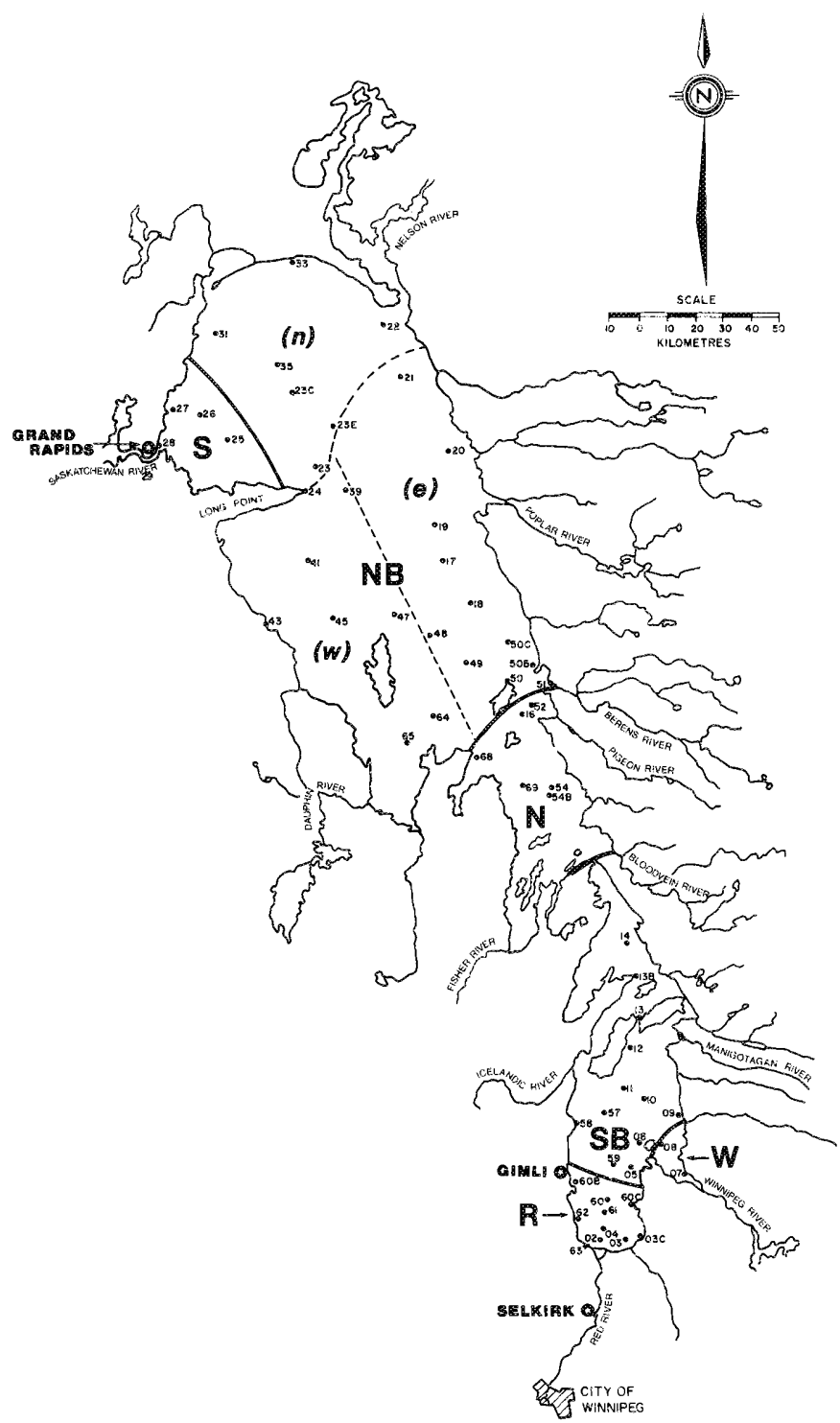

Fig. 1. Location of sampling stations and regionalization in Lake Winnipeg ( $R$, Red River; W, Winnipeg River; SB, main part of the South Basin; N, Narrows; NB, North Basin with subdivisions e (east), w (west), and $\mathrm{n}$ (north); $\mathrm{S}$, Saskatchewan River).

cover all areas of this large lake, $23750 \mathrm{~km}^{2}$ in surface area (Fig. 1). Zooplankton samples were obtained during six consecutive cruises, but due to weather conditions, sampling at all stations was not possible on all cruises: cruise 1, June 4-12, 36 stations; cruise 2, July 9-16, 51 stations; cruise 3, July 24 - August 1, 49 stations; cruise 4, September 2-10, 37 stations; cruise 5, October $3-13,49$ stations; cruise 6 , October 27-31, 25 stations.

At each station, a Wisconsin net of $25-\mathrm{cm}$ mouth diameter and 73- $\mu \mathrm{m}$ mesh size was hauled vertically from just above the lake bottom to the surface at a rate of approximately $0.5 \mathrm{~m} \cdot \mathrm{s}^{-1}$. All the stations were sampled during the daytime hours. The plankton was preserved in $10 \%$ formalin. Measurement of settled net plankton volume was carried out prior to microscopic analysis. Graduated glass tubes, $8 \times 600 \mathrm{~mm}$, were used in which the plankton was allowed to settle for $24 \mathrm{~h}$. At least 200 individuals per sample were counted and identified in a subsample containing about $1 / 40$ of the whole sample. For larger and less numerous animals, either the whole or one fifth of the sample was examined. Identification of adult calanoids was made to species, while copepodids I-V were enumerated as calanoid juveniles and then apportioned amongst various species in accordance with the relative abundance of adults present in the sample. Copepodid stages of cyclopoids were identified to species. Nauplial stages of copepods were identified to family Cyclopidae and to suborder Calanoida. Zooplankton abundance was expressed as the number of specimens per litre, assuming that the filtration efficiency of the net was $100 \%$. In fact, the efficiency was between 45 and $85 \%$, averaging $63 \%$, as indicated by later experiments.

Each basin was subdivided into regions (Fig. 1). Mean abundances in basins were calculated by weighting the zooplankton densities in each region according to the regional share of the total basin area. The morphology, chemistry, and temperature data were collected at the time by Brunskill (1974) and Brunskill et al. (1979a, 1980).

\section{Lake Morphology, Hydrology, Geology, and Climate}

Selected aspects of morphology, hydrology, geology, and climate of Lake Winnipeg and its drainage basins are summarized here to show the complexity of this aquatic system and its potential influence on the planktonic fauna inhabiting it.

The two parts of Lake Winnipeg, the South and North basins, are distinctly separated by the Narrows. The surface area of the North Basin is about six times greater than that of the South Basin, 17520 and $2780 \mathrm{~km}^{2}$, respectively. The Narrows cover an area of $3450 \mathrm{~km}^{2}$. The mean depth of the North Basin is about one third greater than that of the South Basin, 13.3 and $9.7 \mathrm{~m}$, respectively. The two basins differ greatly in the quantity and quality of water received.

There are three major sources of water supply to the lake. The Red River, with its main tributary the Assiniboine River, drains the areas south and west of the lake consisting of nutrientrich sedimentary prairie with extensive agriculture and cities but few lakes. The Saskatchewan River, poorer in nutrients, drains the northern portion of the prairies with many lakes and reservoirs. The Precambrian Shield east of the lake, with its igneous bedrock overlain by variable thicknesses of Glacial Lake Agassiz derived soils, which support the growth of muskegs and boreal forests, is drained mainly by the Winnipeg, Manigotagan, Bloodvein, Pigeon, Berens, and Poplar rivers. This drainage area supports mining and forest industries, little agriculture, and has few large communities.

The South Basin receives $80 \%$ of its annual supply of water from the Precambrian Shield drainage of the Winnipeg River and only $20 \%$ from the sedimentary drainage of the Red River. However, this $20 \%$ supplies as much as $70 \%$ of the total phosphorus to the South Basin, since the concentration of phosphorus in the Red River is at least four times higher than in the Winnipeg River.

A reverse water supply pattern is observed in the North Basin, where $75 \%$ originates from the Saskatchewan River sedimentary drainage with only $25 \%$ from the Precambrian Shield. When inflow from the South Basin is added, the North Basin becomes a mixture of $60 \%$ from Precambrian Shield and $40 \%$ from the sedimentary drainage.

The richest source of nutrients to Lake Winnipeg is the Red River which supplies annually $60 \%$ of the phosphorus and $30 \%$ of the nitrogen. Another major source of sedimentary drainage water, the Saskatchewan River, is poor in nutrients, with total 
TABLE 1. Seasonal changes of mean settled plankton volumes $\left(\mathrm{mm}^{3} \cdot \mathrm{L}^{-1}\right)$ in various regions of Lake Winnipeg, June-October 1969. The regions are designated in Fig. 1. Standard errors in parentheses.

\begin{tabular}{|c|c|c|c|c|c|c|c|c|}
\hline \multirow[b]{3}{*}{ Date } & \multicolumn{8}{|c|}{ Region } \\
\hline & \multicolumn{4}{|c|}{ South Basin } & \multicolumn{4}{|c|}{ North Basin } \\
\hline & $\mathrm{R}$ & W & SB & Mean & $\mathbf{N}$ & NB & $S$ & Mean \\
\hline June 4-12 & $\begin{array}{r}6.35 \\
(1.3)\end{array}$ & $\begin{array}{r}2.77 \\
(0.3)\end{array}$ & $\begin{array}{c}7.13 \\
(1.1)\end{array}$ & $\begin{array}{c}6.83 \\
(0.9)\end{array}$ & $\begin{array}{r}4.57 \\
(2.1)\end{array}$ & $\begin{array}{l}7.16 \\
(1.6)\end{array}$ & $\begin{array}{r}5.14 \\
(0.5)\end{array}$ & $\begin{array}{c}6.86 \\
(1.2)\end{array}$ \\
\hline July $9-16$ & $\begin{array}{c}9.20 \\
(1.3)\end{array}$ & $\begin{array}{c}2.30 \\
(0.8)\end{array}$ & $\begin{array}{l}12.83 \\
(2.3)\end{array}$ & $\begin{array}{l}11.44 \\
(1.4)\end{array}$ & $\begin{array}{r}2.64 \\
(0.2)\end{array}$ & $\begin{array}{r}5.41 \\
(0.9)\end{array}$ & $\begin{array}{c}8.38 \\
(1.2)\end{array}$ & $\begin{array}{c}5.42 \\
(0.7)\end{array}$ \\
\hline July 24 - Aug. 1 & $\begin{array}{l}12.38 \\
(1.6)\end{array}$ & $\begin{array}{r}2.77 \\
(0.4)\end{array}$ & $\begin{array}{c}8.32 \\
(1.1)\end{array}$ & $\begin{array}{c}8.44 \\
(0.9)\end{array}$ & $\begin{array}{c}5.48 \\
(0.7)\end{array}$ & $\begin{array}{r}4.71 \\
(0.5)\end{array}$ & $\begin{array}{c}6.85 \\
(0.7)\end{array}$ & $\begin{array}{c}4.20 \\
(0.3)\end{array}$ \\
\hline Sept. $2-10$ & $\begin{array}{c}15.87 \\
(3.2)\end{array}$ & $\begin{array}{c}3.69 \\
(0.0)\end{array}$ & $\begin{array}{c}6.89 \\
(0.9)\end{array}$ & $\begin{array}{c}7.64 \\
(1.2)\end{array}$ & $\begin{array}{c}2.64 \\
(0.2)\end{array}$ & $\begin{array}{l}11.35 \\
(1.6)\end{array}$ & $\begin{array}{l}15.61 \\
(2.5)\end{array}$ & $\begin{array}{l}11.06 \\
(1.4)\end{array}$ \\
\hline Oct. $3-13$ & $\begin{array}{c}6.98 \\
(0.7)\end{array}$ & $\begin{array}{c}0.92 \\
(0.1)\end{array}$ & $\begin{array}{c}3.33 \\
(0.4)\end{array}$ & $\begin{array}{c}3.58 \\
(0.4)\end{array}$ & $\begin{array}{c}2.44 \\
(0.4)\end{array}$ & $\begin{array}{c}9.95 \\
(1.9)\end{array}$ & $\begin{array}{c}8.38 \\
(1.8)\end{array}$ & $\begin{array}{r}9.39 \\
(1.5)\end{array}$ \\
\hline Oct. $27-31$ & $\begin{array}{c}4.44 \\
(1.3)\end{array}$ & $\begin{array}{r}2.77 \\
(0.3)\end{array}$ & $\begin{array}{c}3.33 \\
(0.5)\end{array}$ & $\begin{array}{r}3.41 \\
(0.4)\end{array}$ & $\begin{array}{c}2.03 \\
(0.2)\end{array}$ & $\begin{array}{c}3.67 \\
(0.7)\end{array}$ & $\begin{array}{l}10.47 \\
(3.2)\end{array}$ & $\begin{array}{r}3.99 \\
(0.8)\end{array}$ \\
\hline
\end{tabular}

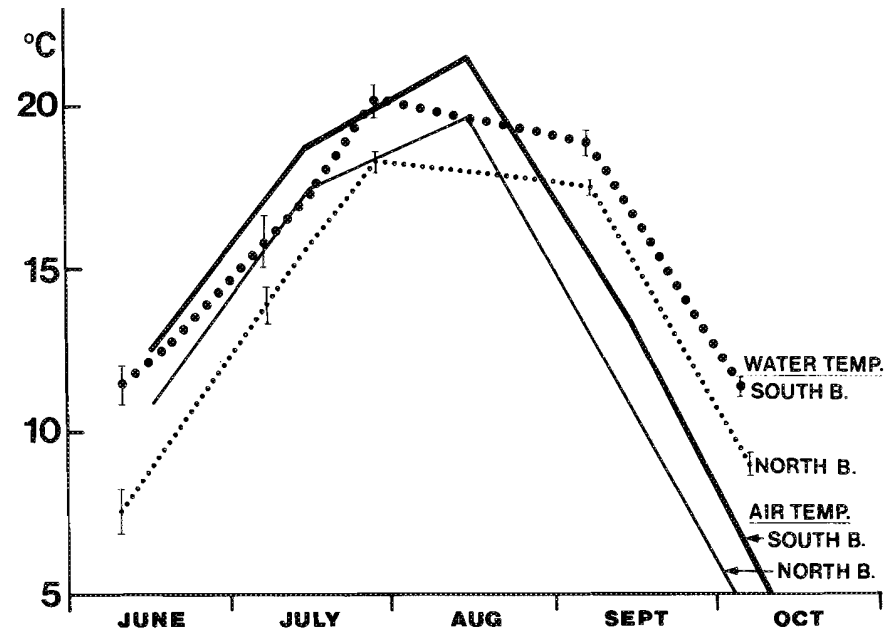

Fig. 2. Climatic differences between the northern and southern ends of Lake Winnipeg. The continuous lines denote the south and north end mean ( $\pm \mathrm{SE}$ ) monthly air temperatures; the dotted lines show the corresponding water temperatures (averaged over the upper $10-\mathrm{m}$ layer).

phosphorus concentration one third that in the Red River. The above values are rough approximations of published records (Brunskill et al. 1979a).

Added to the complexities of water supply are the climatic differences between the northern and southern ends of the lake, which span $3.5^{\circ}$ of latitude. Differences in air temperature between the north and south ends of the lake are observed in meteorological records from Grand Rapids and Gimli or Selkirk, respectively (Fig. 1 and 2) (Anonymous 1929-68). On average, air temperatures are $1.72^{\circ} \mathrm{C}$ warmer at the southern end of the lake, with north-south differences ranging from 1.0 to $2.6^{\circ} \mathrm{C}$ from June to November. Similarly, water temperatures of the upper 10-m stratum in the South Basin are on average $1.77^{\circ} \mathrm{C}$ warmer (range $1.2-4.2^{\circ} \mathrm{C}$ ) than in the North Basin. Lake water temperatures lag behird air temperatures by about $6-12 \mathrm{~d}$ in both the June-August warming period and during the Sep-

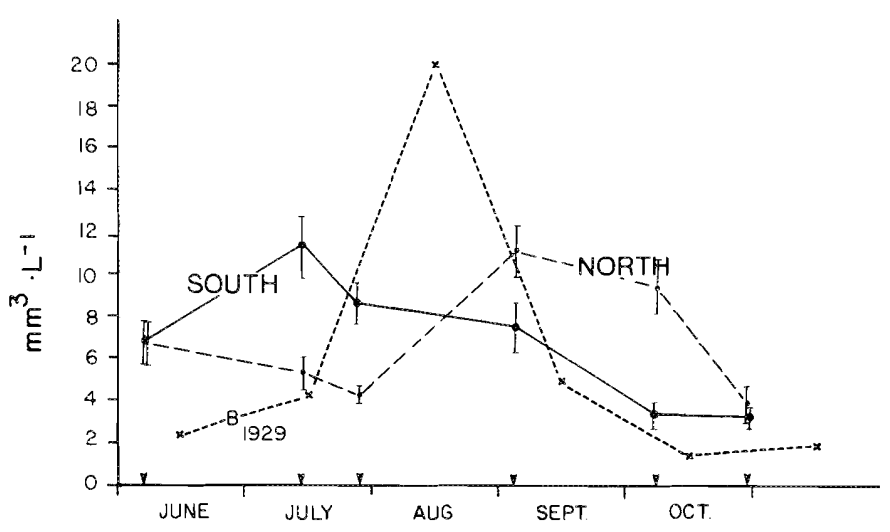

Fig. 3. Seasonal changes of mean ( $\pm \mathrm{SE}$ ) areal-weighted settled plankton volumes in the North and South basins of Lake Winnipeg. B denotes Bajkov's 1929 lake averages (Bajkov 1934).

tember-October cooling period. Another expression of climatic difference is the number of frost-free days, amounting to 100 in the North Basin and 120 in the South Basin (Anonymous 1929-68).

\section{Results}

\section{Settled Net Plankton Volume}

The simplest indication of planktonic biomass is the settled volume of material collected by the Wisconsin net in vertical hauls. Since the samples consist of both large phyto- and zooplankton in varying proportions, the method provides data for only a general characterization of lake productivity and spatial complexity (Table 1; Fig. 3). Although the seasonal average plankton volumes in the North and South basins were not much different $\left(6.82\right.$ and $6.97 \mathrm{~mm}^{3} \cdot \mathrm{L}^{-1}$, respectively), their seasonal distributions were. Maximum volumes of plankton in the North Basin were observed in September and October, i.e. 1-2 mo later than in the South Basin.

Plankton volumes varied considerably within each basin. Plankton was consistently poorest in area in Winnipeg River 


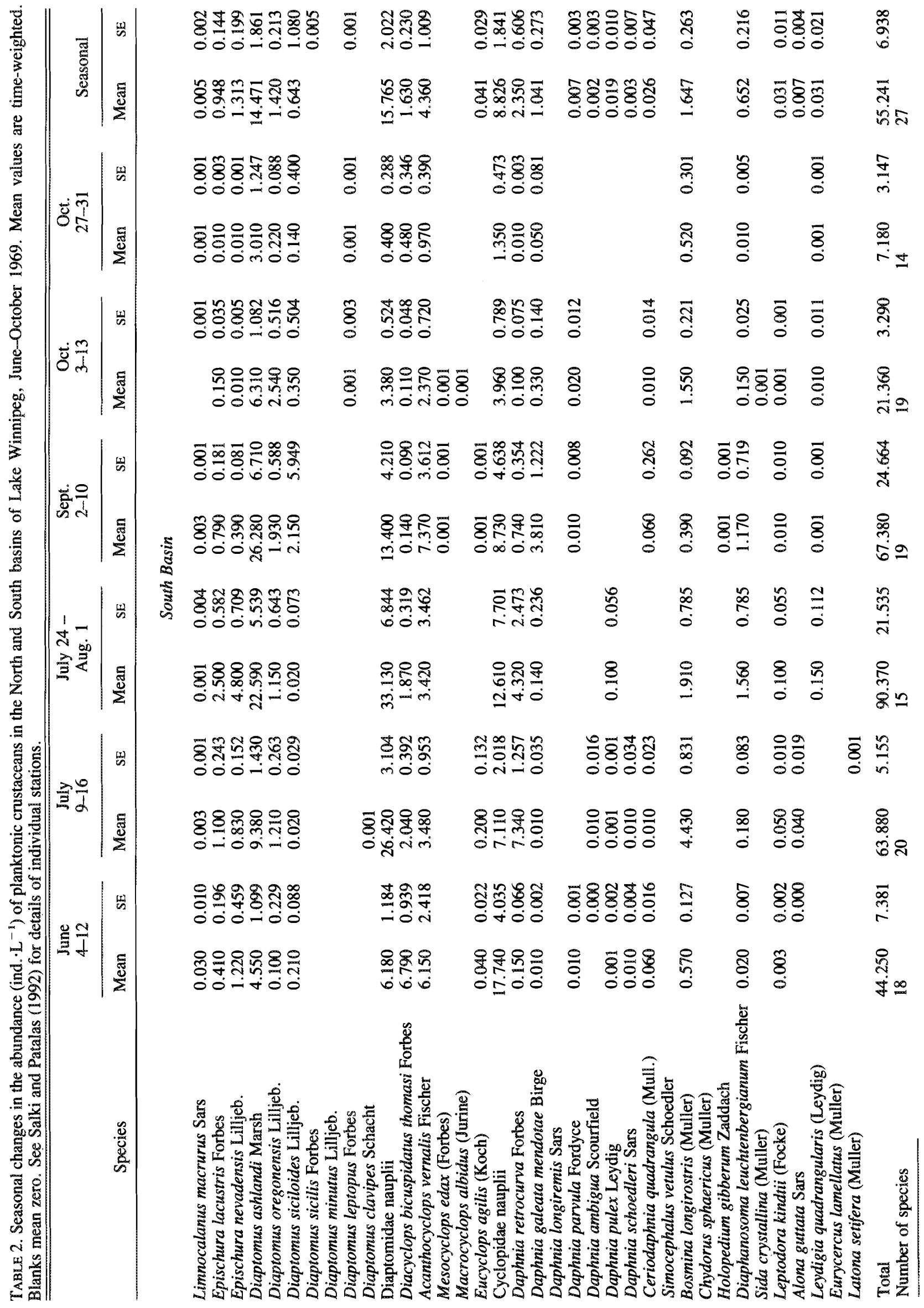


TABLE 2. (Concluded)

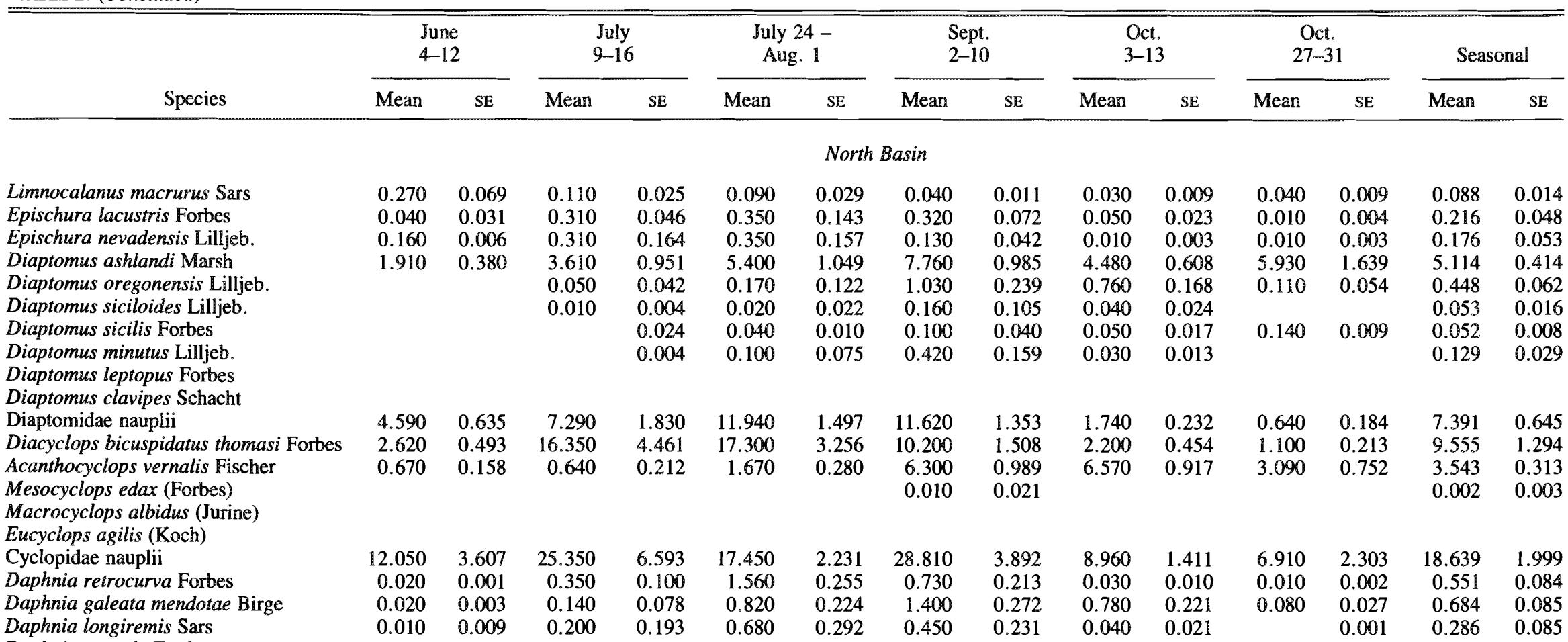

Daphnia parvula Fordyce

Daphnia ambigua Scourfield

Daphnia pulex Leydig

Daphnia schoedleri Sars

Ceriodaphnia quadrangula (Mull.)

Simocephalus vetulus Schoedler

Bosmina longirostris (Muller)

Chydorus sphaericus (Muller)

Holopedium gibberum Zaddach

Diaphanosoma leuchtembergianum Fischer 0.010

Sida crystallina (Muller)

Leptodora kindtii (Focke)

Alona guttata Sars

$0.003 \quad 0.001$

$0.193 \quad 0.680$

0.292

$0.450 \quad 0.231$

$0.040 \quad 0.02$

0.286

0.085

Leydigia quadrangularis (Leydig)

Eurycercus lamellatus (Muller)

Latona setifera (Muller)

Total

$22.700 \quad 4.230 \quad 58.420$

Number of species

13

16

$10.953 \quad 62.780$

17

5.855

71.400

7.832

0.001 
$4.3 \%$ of the total abundance in North and South basins, respectively, Bosmina longirostris with 3.9 and $3.2 \%$, Daphnia galeata mendotae with 1.2 and $1.5 \%$, and Diaphanosoma leuchtenbergianum with 0.4 and $1.1 \%$.

The generalized structure of the major components of the Lake Winnipeg planktonic communities (Fig. 4) indicates that filtrators (diaptomids and cladocerans) were numerically predominant in the South Basin (71.5\%), while omnivores and predators (cyclopoids) dominated the North Basin $(63.8 \%$ ).

\section{Seasonal Changes in the Horizontal Distribution and Abundance of Planktonic Crustaceans}

In spite of the intensive vertical water column mixing in Lake Winnipeg, the horizontal distribution of water masses and planktonic crustaceans was far from uniform. On many occasions, large differences in zooplankton densities existed among stations. These significant differences persisted throughout the season for some species, while densities varied from month to month for others. This complexity of the spatial distribution of individual species complicates the task of analysis of seasonal changes in abundance of these species. Sampling at the same stations over time does not necessarily provide information on the seasonal history of a population because the water mass in which a population lives may be affected by variable river discharges and wind speed and direction which cause it to move in unpredictable ways. Water mass boundaries and their consecutive positions cannot be easily established. Therefore, one must average over larger areas such as the South and North basins to provide reasonable values reflecting seasonal changes in plankton abundance. As the average net water residence times in the South and North basins $(0.5$ and $2.5 \mathrm{yr}$, respectively; Brunskill et al. 1980) were very much longer than the sampling intervals, one could assume that the same water mass was often sampled regardless of its actual location within the basin.

In the South Basin, total numbers of crustaceans during the first half of the open-water season were from 10 to $100 \%$ greater than in the North Basin (Fig. 5). Initial (June) densities were about twice as high in the South Basin as in the North Basin (44 and 23 ind. $\cdot L^{-1}$, respectively). From June to August, numbers steadily increased at about the same rate in both basins. The South Basin peak preceded that in the North Basin by about 1 mo. From September to October, crustacean abundance decreased in both basins. At the end of the season in October, numbers in the South Basin were about half those of the North Basin, a reversal of the pattern during the first half of the openwater season. The patterns of seasonal changes of planktonic crustaceans were mainly produced by three copepod species. $D$. ashlandi, D. bicuspidatus thomasi, and A. vernalis contributed more than $80 \%$ to the total number of crustaceans, while all 19 species of cladocerans constituted no more than $5 \%$ of the total. The three dominant copepods, however, exhibited marked differences in their developmental patterns in the two basins.

\section{Copepods}

Diaptomus ashlandi (Fig. 6a) was most abundant in the South Basin, particularly in the vicinity of the Red River inlet (stations 2 and 3) and along the western shore (station 58), reaching levels of $98.8 \mathrm{ind} \cdot \mathrm{L}^{-1}$ in July. It was relatively scarce in the Winnipeg River - Traverse Bay area (stations 7 and 8), never exceeding 1.6 ind. $\cdot \mathrm{L}^{-1}$. North Basin abundances were usually two to five times lower than those of the South Basin, with a tendency to increase southward. Frequently, the highest numbers within the North Basin were observed along the eastern shore, particularly in the vicinity of stations 20 and $21(23.7$ ind. $\mathrm{L}^{-1}$ in July and $25.8 \mathrm{ind} \cdot \mathrm{L}^{-1}$ in October).

Diaptomus ashlandi reached maximum abundance in the South Basin by late July but declined to a minimum by October (Fig. 5). In the North Basin, the rate of increase was much slower, with a slight peak in September and a slight increase in October.

Diaptomus oregonensis (Fig. 6b) appeared in June near the Red River mouth and spread gradually throughout the South Basin except near Traverse Bay, where it was always absent. In the North Basin, this species appeared initially in July in the Pigeon Bay area (stations 16 and 52) and at the Saskatchewan River mouth (station 28), spreading by midsummer over the entire basin but existing in very low numbers. Diaptomus ore gonensis barely reached $1 / 10$ the density of $D$. ashlandi. More abundant in the South Basin, it gradually increased in numbers, reaching a peak in September and early October. In the North Basin, its development was marked by the characteristic delay, being absent there in June and July (Fig. 5).

Diaptomus siciloides (Fig. 6c) was found in rather restricted areas, occurring near the mouths of the Red and Saskatchewan rivers in abundance generally below 5 ind. $L^{-1}$. Only at station 2 near the Red River in September did it reach an abundance as high as $11.7 \mathrm{ind} \cdot \mathrm{L}^{-1}$. In late July and October, it was also found in the area adjacent to the Warpath River south of Long Point. It was about 10 times more numerous in the South Basin than in the North Basin (Fig. 5).

Diaptomus sicilis (Fig. 7a) occurred in very low numbers throughout the season, being found mainly in the autumn along the eastern shore of the North Basin (stations 20 and 21) and in an area around Berens Island (station 50). It was absent in the South Basin.

Diaptomus minutus (Fig. 7b) was restricted to the northern part of the North Basin associated mostly with the Saskatchewan River mouth area.

Diaptomus leptopus was found only in October and only in a few stations located near the Red River inflow.

Diaptomus clavipes was present as a single specimen recorded in early July near the mouth of the Red River.

Epischura lacustris (Fig. 7c) and Epischura nevadensis (Fig. 8a) were found all over the lake but were, on average, about four to eight times more abundant in the South Basin than in the North Basin. Their distribution was confined mainly to the central and southern parts of the South Basin where abundances were at least 10-20 times higher than those in the North Basin. While in most cases both species were found together in the same sample, $E$. nevadensis was almost twice as abundant as $E$. lacustris in the South Basin. In the North Basin, the numbers of both species were similar. The copepodids of both species (Fig. 8b) were, as their adult forms, more abundant in the South Basin, but as a rule, they were absent in the plumes of the Winnipeg and Red rivers. Epischura lacustris and $E$. nevadensis displayed similar seasonal patterns. Their numbers, low at the beginning of the open-water season, reached a maximum in July and declined thereafter.

Diaptomus and Epischura nauplii (Fig. 8c) were distributed all over the lake throughout the summer, but maximal numbers occurred in the South Basin, particularly in the area adjacent to the Red River, with 135.5 ind. $\cdot L^{-1}$ in July, densities about 10 times higher than those in the North Basin. They showed a 

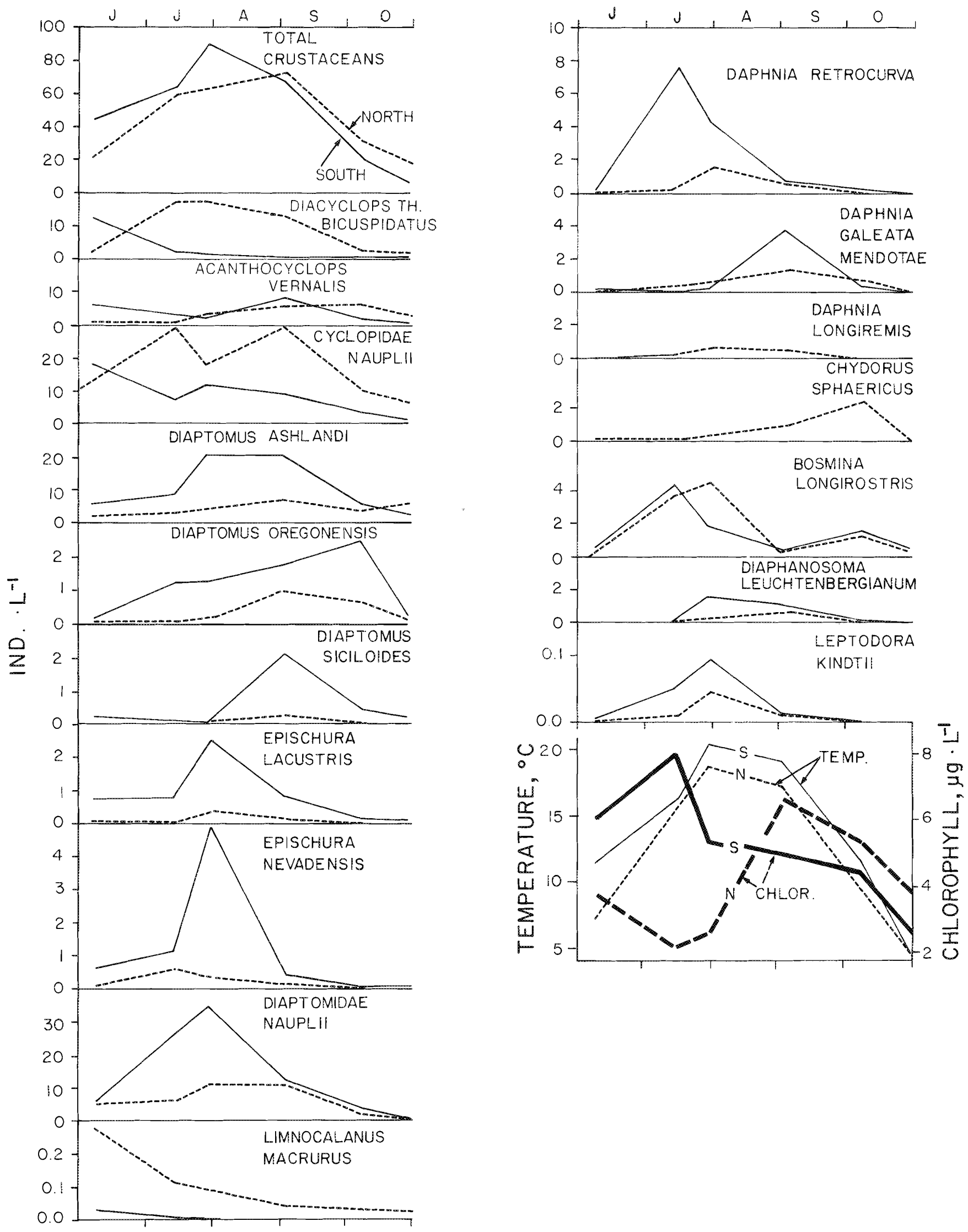

Fig. 5. Changes in the abundance of various species of crustaceans, mean temperature at $0-10 \mathrm{~m}$, and chlorophyll a concentration in the North (N) and South (S) basins, June-October 1969. 

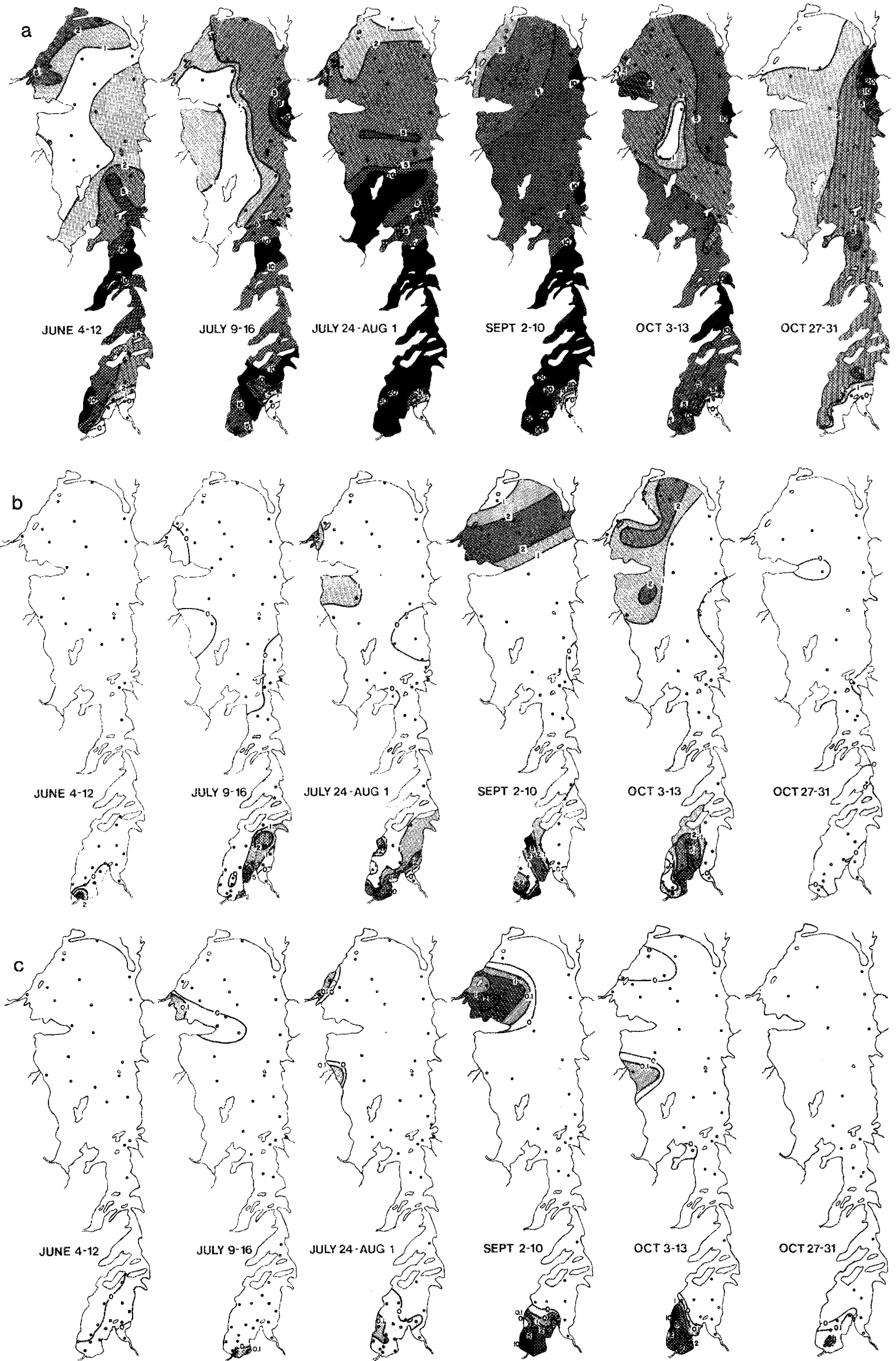

FIG. 6. Spatial distribution (ind. $\cdot \mathrm{L}^{-1}$ ) of adults and copepodids of (a) Diaptomus ashlandi, (b) Diaptomus oregonensis, and (c) Diaptomus siciloides in Lake Winnipeg, June-October 1969. 

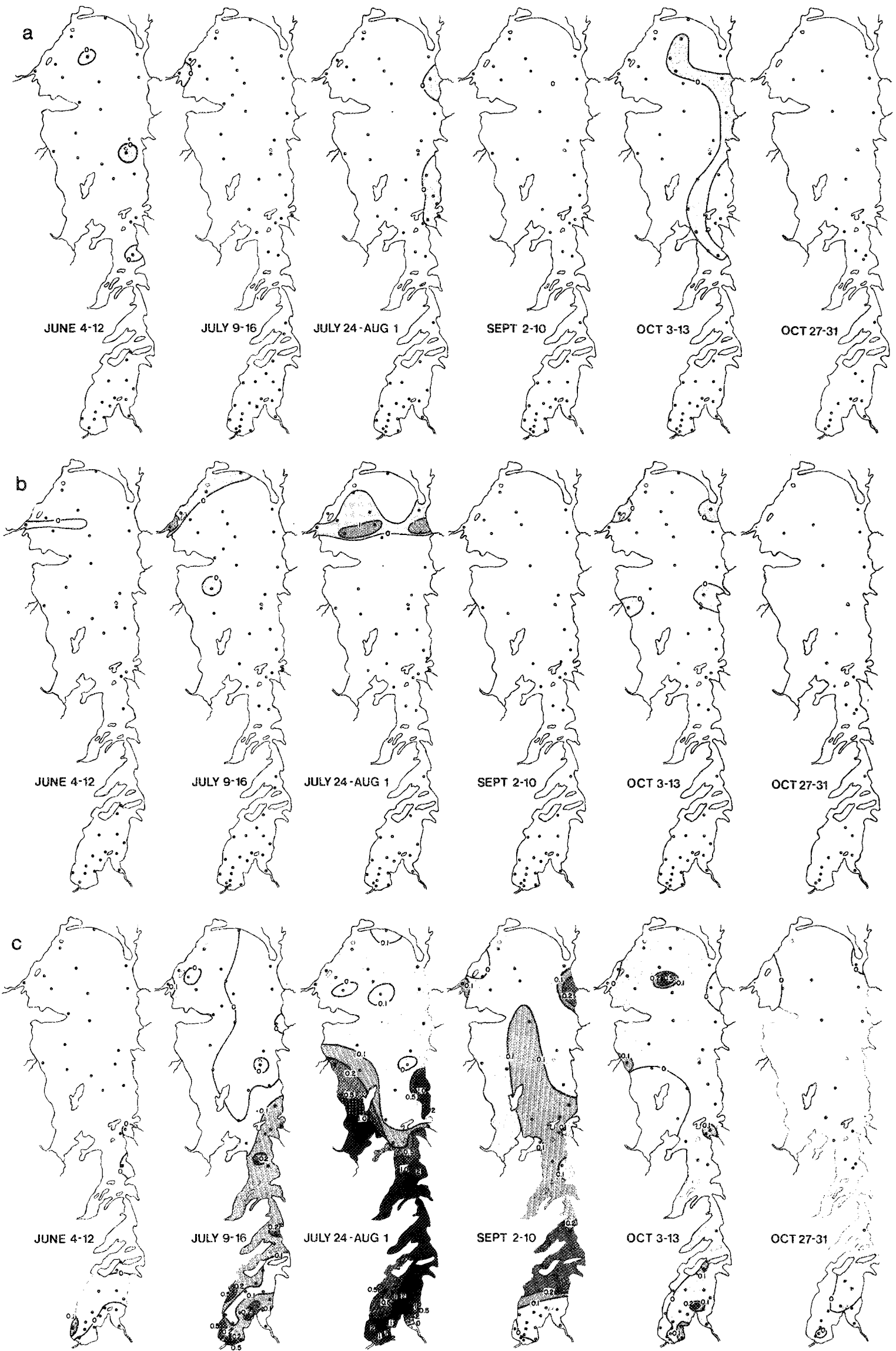

FIG. 7. Spatial distribution (ind. $\mathrm{L}^{-1}$ ) of adults and copepodids of (a) Diaptomus sicilis, (b) Diaptomus minutus and (c) adults of Epischura lacustris in Lake Winnipeg, June-October 1969. 

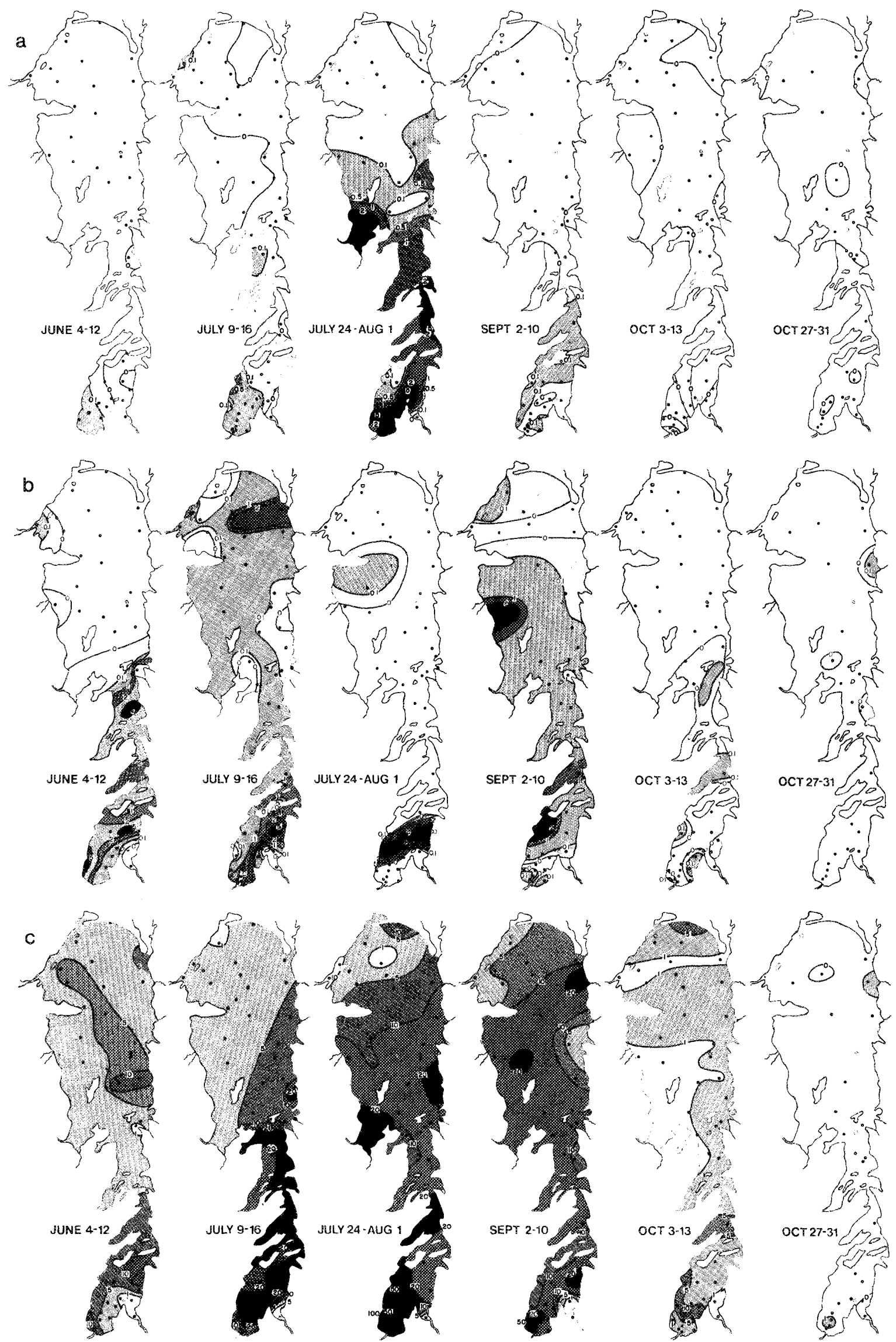

Fig. 8. Spatial distribution (ind. $\cdot \mathrm{L}^{-1}$ ) of (a) adults of Epischura lacustris, (b) copepodids of Epischura sp., and (c) nauplii of Diaptomus sp. and Epischura sp. in Lake Winnipeg, June-October 1969. 

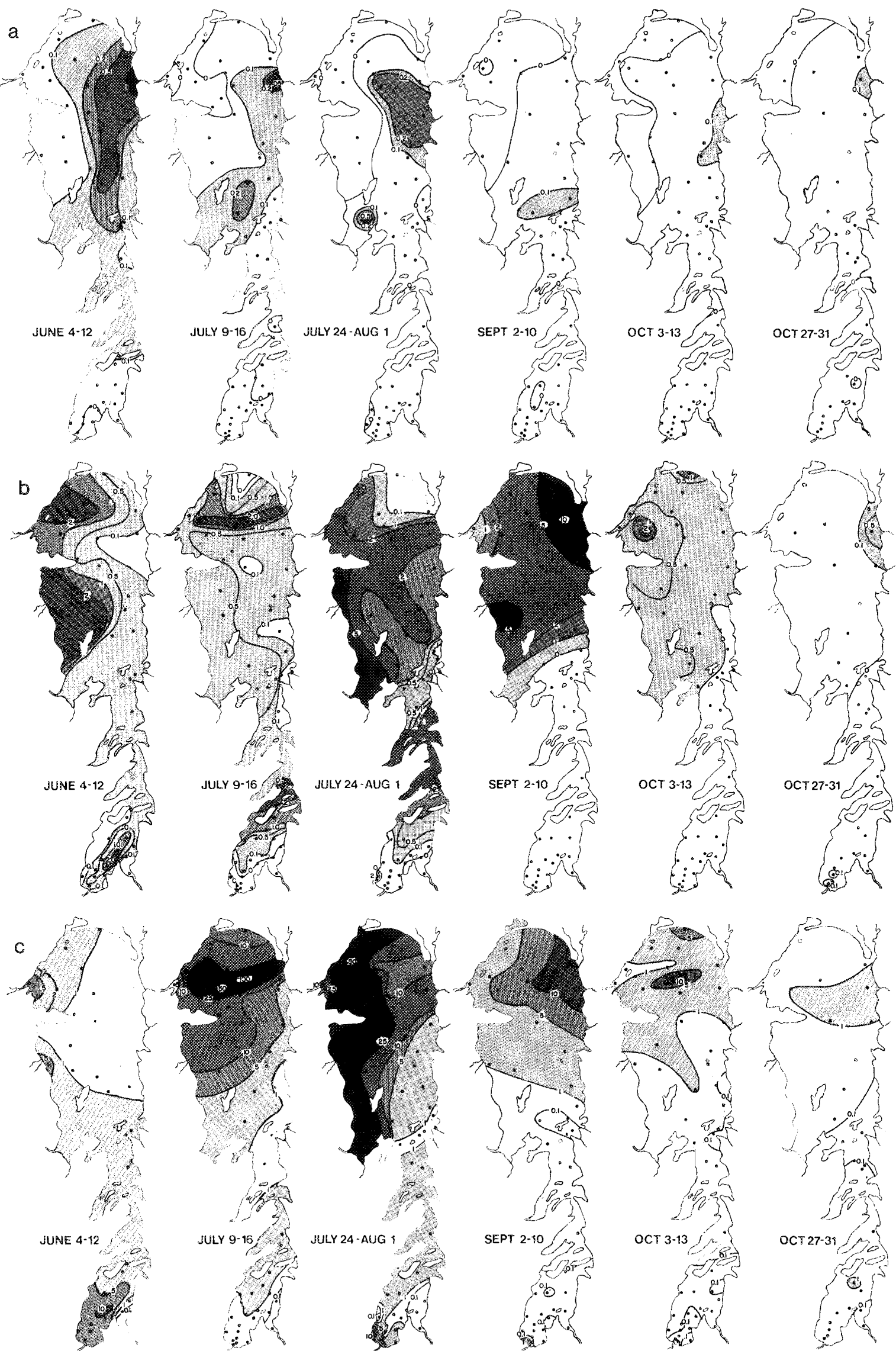

Fig. 9. Spatial distribution (ind. $\cdot \mathrm{L}^{-1}$ ) of (a) adults and copepodids of Limnocalanus macrurus, (b) adults of Diacyclops bicuspidatus thomasi, and (c) copepodids mainly of Diacyclops bicuspidatus thomasi in Lake Winnipeg, June-October 1969. 
seasonal distribution very closely resembling that of D. ashlandi, with a July maximum in the South Basin and a July-September maximum in the North Basin.

Limnocalanus macrurus (Fig. 9a) was present in June all over the lake with the exception of the area adjacent to the Red River inlet. The highest densities $\left(1.0\right.$ ind. $\left.\cdot \mathrm{L}^{-1}\right)$ were found mainly in the deepest part of the North Basin, a strip running from Reindeer and Berens islands (stations 47 and 50) to the Nelson River outflow (station 22). The species gradually disappeared from the South Basin over the course of the summer but continued to maintain higher levels in the deepest, eastern portion of the North Basin. Very few specimens were encountered in the area adjacent to Saskatchewan River inlet. Mean abundance of $L$. macrurus in the North Basin continuously decreased throughout the summer (Fig. 5). Similar patterns were found in the South Basin, but with very low initial numbers, $L$. macrurus almost completely disappeared from this part of the lake by September. The nauplial stages were found only in June and only in the deepest part of the North Basin.

Diacyclops bicuspidatus thomasi (Fig. 9b and 9c) was the most abundant crustacean in the summer plankton of Lake Winnipeg. Three centres of abundance could be identified in June: one in the central part of the South Basin, the second in the North Basin between Reindeer Island and Long Point, and the third north of Long Point. In the South Basin (Fig. 5), highest densities occurred in the first month of sampling, June, suggesting that perhaps maximum population densities may have been reached prior to this date. Mean numbers in the South Basin gradually decreased during July, and by September, both adults and copepodids had almost completely disappeared (see also Fig. $9 \mathrm{~b}$ and $9 \mathrm{c}$ ). In contrast, the North Basin population was lower in abundance in June and reached a maximum in July, at least 1 mo later than in the South Basin. Numbers gradually decreased during September and October, but never to the low levels observed in the South Basin. On average, the North Basin population was four to five times more abundant than the South Basin population.

Acanthocyclops vernalis (Fig. 10a), second to D. bicuspidatus thomasi in abundance, demonstrated a very different pattern of distribution. Throughout June and July, highest numbers were always found in the most southern portion of the South Basin, in the immediate vicinity of the Red River inflow. At the same time, areas adjacent to the Winnipeg River were almost completely devoid of $A$. vernalis as well as all other crustaceans. In the North Basin, A. vernalis was found everywhere during the summer, but usually in quantities lower than those in the South Basin (Fig. 5). By October, the pattern was reversed, with about three times more animals found in the North Basin.

Mesocyclops edax was found only sporadically in September and October in the areas adjacent to the mouths of the Saskatchewan, Red, and Winnipeg rivers.

Eucyclops agilis was encountered in very small numbers in June and early July, exclusively in the South Basin, mainly in the areas adjacent to the Red and Winnipeg River mouths.

Macrocyclops albidus was found only once in October near the Winnipeg River mouth.

Cyclopidae nauplii (Fig. 10b and 5), common to all areas of the lake, had densities mostly between 10 and 50 ind. $\cdot \mathrm{L}^{-1}$. The exception was, however, the area adjacent to the Red River, with abundances much higher than lake average. In contrast, nauplii were almost entirely lacking in the Traverse Bay -
Winnipeg River mouth area throughout the investigation. Cyclopidae nauplii demonstrated two pulses, in June and in late July in the South Basin and in July and September, after about 1-mo delay, in the North Basin (Fig. 5). On average, their densities were about twice as high in the North Basin than in the South Basin, as was overall cyclopoid abundance. In both basins, nauplii amounted to $59 \%$ of the total cyclopoid population.

\section{Cladocerans}

Daphnia retrocurva (Fig. 11a and 5) was the most abundance cladoceran species in Lake Winnipeg, although it contributed only 1 and $4 \%$ to the total number of crustaceans in the North and South basins, respectively. In comparison, the dominant copepod species, $D$. ashlandi, was about 10 times more abundant. Daphnia retrocurva appeared initially in June around the Red River inlet in the South Basin and at the few stations in the North Basin located near the Saskatchewan and Pigeon River mouths. By early July, the species had spread throughout the lake, reaching abundances in the South Basin which were 20 times higher than in the North Basin. Low abundances were always associated with the Nelson River outlet area in the eastern part of the lake. Numbers declined to very low levels by September, and by October, $D$. retrocurva disappeared from most regions of the lake except for small pockets near the Red and Saskatchewan River mouths.

Daphnia galeata mendotae (Fig. $11 \mathrm{~b}$ and 5) was found in June in most parts of the lake in very low numbers, less than 0.1 ind $\cdot L^{-1}$. A gradual increase was evident throughout the lake in July, and by September, a maximum of 1 and 3 ind. $\cdot \mathrm{L}^{-1}$ in the North and South basins, respectively, was reached. In some stations around the Red and Saskatchewan river inlets, densities of 5-15 ind. $\mathrm{L}^{-1}$ were found. The population diminished in late October to very low numbers, usually less than 0.1 ind. $\cdot \mathrm{L}^{-1}$. The abundance of $D$. galeata mendotae was usually greater in the North Basin.

Daphnia longiremis (Fig. 11c and 5) was confined to the North Basin, at a centre of distribution associated with the Saskatchewan River inlet area where, in July, numbers reached a maximum of $1-6$ ind. $\cdot L^{-1}$. From this region, a gradual eastward spread occurred during June and July. In September and October, the species' centre of distribution moved along the northern shore towards the Nelson River outlet.

The following four daphnids were observed only as single specimens per sample: Daphnia parvula (Fig. 10c, A) in four stations located in close proximity to the Red River inlet from June to October, Daphnia ambigua (Fig. 10c, B) only once in July, close to the Red River inlet, and Daphnia pulex (Fig. 10c, C) and Daphnia schoedleri (Fig. 10c, D) in June and early July in 10 stations located in the central and southern parts of the South Basin. The taxonomic position of some individuals of the latter two species was not always clear. Many specimens with intermediate features between these two species were frequently found.

Ceriodaphnia quadrangula (Fig. 12a) was restricted to the South Basin, most frequently found around the Red River inlet where, in September, the highest density of $5 \mathrm{ind} . \mathrm{L}^{-1}$ was encountered.

Simocephalus vetulus was found once as a single specimen in September near the Saskatchewan River inlet.

Bosmina longirostris (Fig. 12b) was distributed throughout the lake for most of the season, with abundances ranging 

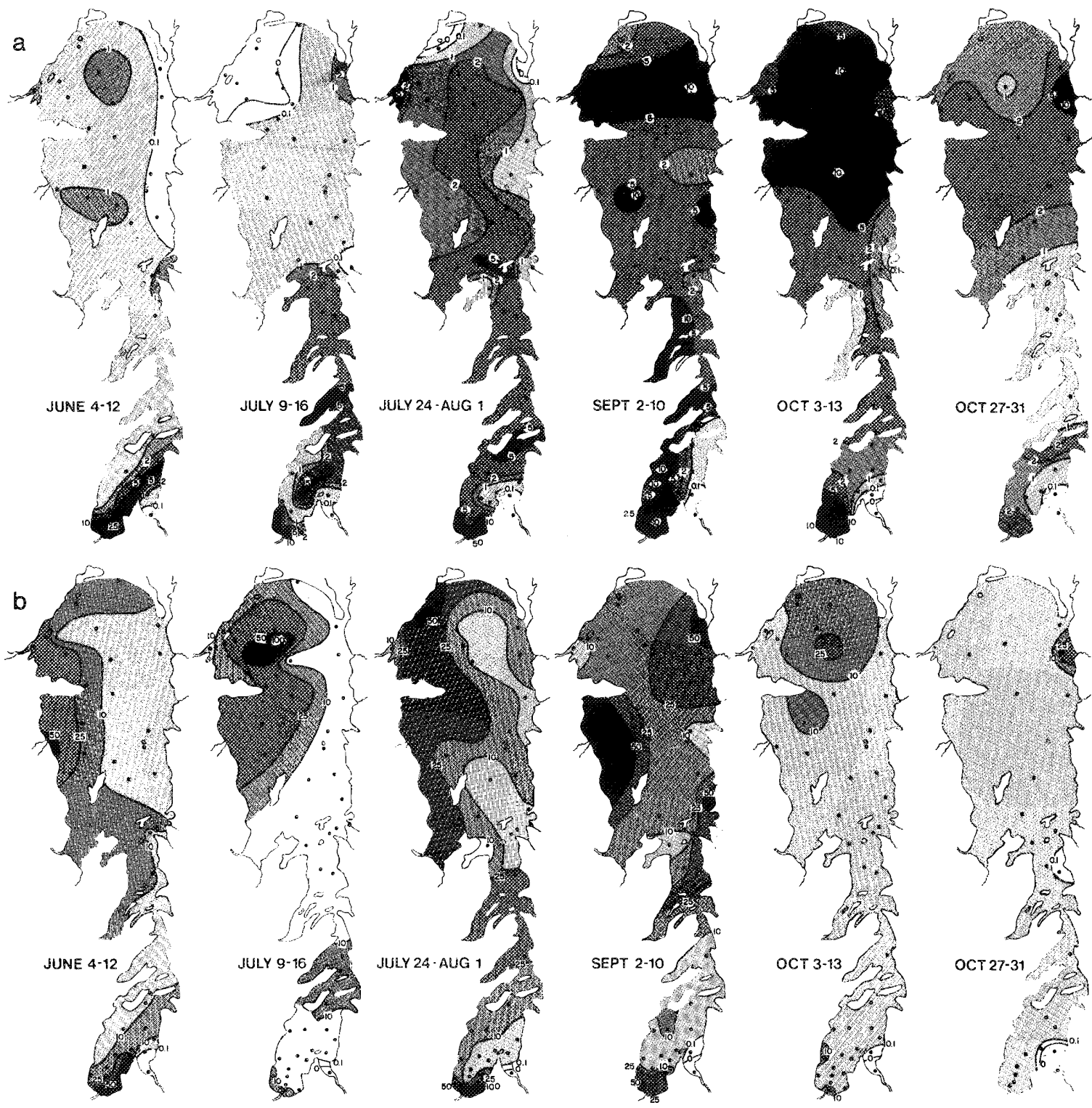

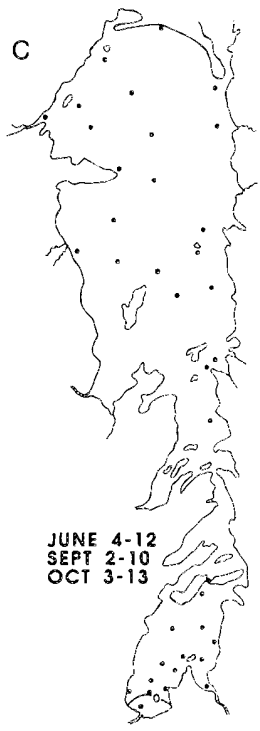

A

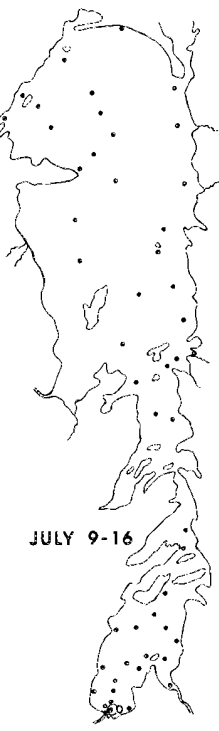

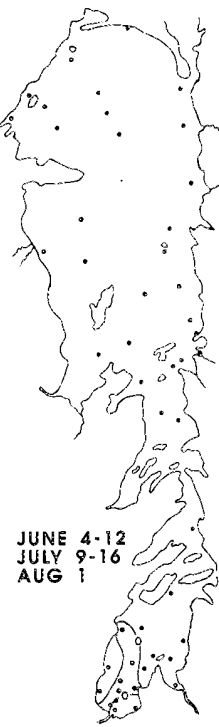

C

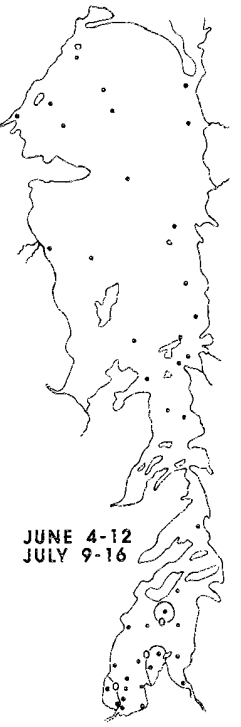

D

FIG. 10. Spatial distribution (ind. $\mathrm{L}^{-1}$ ) of (a) adults and copepodids of Acanthocyclops vernalis, (b) nauplii of Cyclopidae, and (c) single specimens of Daphnia parvula (A), Daphnia ambigua (B), Daphnia pulex (C), and Daphnia schoedleri (D) in Lake Winnipeg, June-October 1969. 

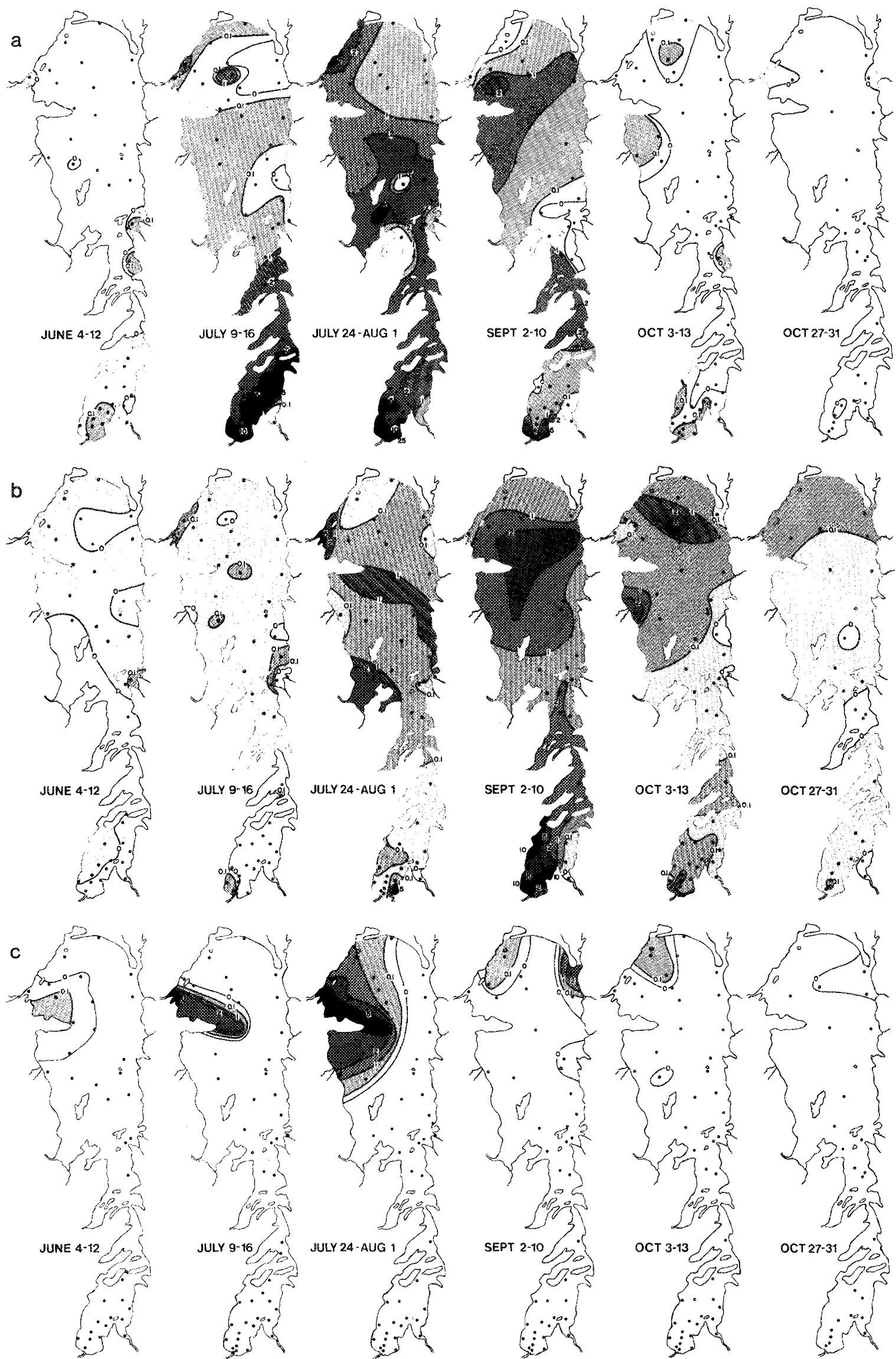

Fig. 11. Spatial distribution of (ind $\cdot \mathrm{L}^{-1}$ ) of adults and juveniles of (a) Daphnia retrocurva, (b) Daphnia galeata mendotae, and (c) Daphnia longiremis in Lake Winnipeg, June-October 1969. 
between 1 and 5 ind. $\cdot \mathrm{L}^{-1}$. Two main centres of abundance with up to 17 ind. $L^{-1}$ were apparent, one in the vicinity of the Red River and the other near the Saskatchewan River inlet. Numbers were minimal in Traverse Bay and stations along the northeastern shores of the lake for most of the period. Bosmina longirostris (Fig. 5) reached its maximum abundance in early and late July in the South and North basins, respectively. Following a decline in September, a second smaller peak was observed in early October in both basins.

Chydorus sphaericus (Fig. 12c), like D. longiremis, was encountered only in the northern part of the North Basin, localized near the Saskatchewan River mouth and in the area between Reindeer Island and Long Point peninsula. Even during the period of its maximum abundance in September and October, this species did not expand beyond these regions. In late October, $C$. sphaericus occupied only a narrow strip extending between the Saskatchewan River inlet and the Nelson River outlet.

Leptodora kindtii (Fig. 13a) occurred in June in areas adjacent to the Saskatchewan, Red, and Pigeon River inflows. By late July it had spread over the entire lake, with maximum densities of $0.2-0.5$ ind. $\cdot L^{-1}$ occurring in nearshore waters. Population counts declined in September, with a marked absence of specimens from central areas of both the North and South basins. In early October, only a few Leptodora were found near the Red and Saskatchewan River inflows, and by late October the species had completely disappeared from the lake water. Leptodora were never found in the Winnipeg River mouth area. South Basin numbers averaged three times higher than those in the North Basin (Fig. 5).

Diaphanosoma leuchtenbergianum (Fig. 13b) was found first in the South Basin and then spread throughout the lake in midsummer. Two areas of maximum densities were recorded, the first near the Red River inlet and the second in the North Basin in a strip between the Saskatchewan River inflow and Nelson River outflow. Diaphanosoma leuchtenbergianum was never found near the Winnipeg River inflow, and only a few specimens were encountered within the Pigeon River inflow. Diaphanosoma leuchtenbergianum appeared in Lake Winnipeg relatively later than most other crustacean species (Fig. 5). In the South Basin it reached maximum densities in late July, while in the North Basin it crested 1 mo later in September. On the average, three times greater densities were found in the South Basin than in the North Basin.

Leydigia quadrangularis was encountered from July to October only in a narrow strip adjacent to the Red and Winnipeg River inflows.

Sida crystallina and Latona setifera were found only once in October, and Alona guttata was found in June near the Red River inlet and Eurycercus lamellatus in October in the North Basin. Holopedium gibberum was found only once in September near the Winnipeg River inflow.

The spatial distribution of the entire crustacean community (Fig. 13c) exhibited a rather definite, nonrandom pattern. In the western part of the North Basin, particularly in the vicinity of the Saskatchewan river inflow, high numbers of crustaceans were found in spring and summer, on average 5-20 times higher than in the eastern part. A more uniform distribution throughout the entire basin was observed in September and October, when zooplankton abundance decreased gradually with decreasing water temperature.

In the South Basin, high plankton densities were observed in the central and southern parts, particularly in the vicinity of the Red River inflow. Conversely, the Winnipeg River - Traverse Bay area was always poor in crustaceans, with counts 100 times lower than those in the Red River inflow region. As a result of the Winnipeg River impoverishing effect, the northern part of the South Basin was always lower in numbers than the southern portion of the basin.

\section{Discussion}

Thirty-four species of planktonic crustaceans were found in Lake Winnipeg during the open-water period from June to October, and as many as 30 of these species occurred in the summer months (July to the beginning of September; Table 2). The number can be reduced to 27 by subtracting some littoral chydorids. This is a rather high number of species, since the comparable numbers for other North American great lakes are lower, i.e. Lake Superior, 18; Lake Huron, 23; Lake Ontario, 23; Lake Erie, 21-25 (Patalas 1972). The analysis of the individual maps of species distribution (Fig. 6a-13b) revealed, however, a planktonic community in Lake Winnipeg with a very specific spatial structure (Fig. 14). Of the 34 species, only 12 were distributed throughout the main body of the lake. The remaining 22 species were found exclusively in restricted areas near the river inflows. They enter the system, but for some reason do not spread throughout it. The points of entry of these species are clearly identifiable: $D$. sicilis enters from the Precambrian Shield drainage areas via the Berens, Mukatawa, and Poplar rivers, $D$. longiremis and $D$. minutus come solely from the Saskatchewan River, and $D$. siciloides and $D$. oregonensis are brought by rivers flowing from the sedimentary basin, i.e. the Saskatchewan, Warpath, and Red rivers. Mesocyclops edax invades the lake in very small numbers in the autumn from three major rivers, the Saskatchewan, Red, and Winnipeg. Chydorus sphaericus enters from the northwest but surprisingly is not found in the vicinity of the Red River inflow even though it is considered to be one of the most widespread cladocerans. $\mathrm{Hol}$ opedium gibberum, one of the most widely distributed cladocerans in Canada, was found only once in very small numbers near the Winnipeg River inflow. Several daphnids, $D$. schoedleri, D. pulex, D. ambigua, D. parvula, and C. quadrangula, arrive only by the Red River and do not expand beyond the river inflow area.

Thus, one can distinguish two groups in the planktonic community, a "core" of 12 established species and the remaining 22 "marginal," unsuccessful invaders (Patalas 1981). It seems possible that the marginal species might constitute a potential replacement pool if some core components were eliminated by changing environmental conditions. Such a planktonic community structure could ensure quick adaptation of the community to changing abiotic and biotic conditions.

The perception of the complexity of a system is a function of the level of resolution applied in the observation. This general statement is particularly illustrated in the analysis of the crustacean plankton of Lake Winnipeg. When the resolution is limited to seasonal mean total crustacean abundance, only small differences between the North and South basins are found (50 and 55 ind. $\left.\cdot \mathrm{L}^{-1}\right)$. Greater differences, are, however, visible when the seasonal and geographic dimensions are examined. South Basin plankton abundances appear to increase much faster than those in the North Basin (Fig. 5). After the total crustacean plankton was subdivided into three major taxonomic 

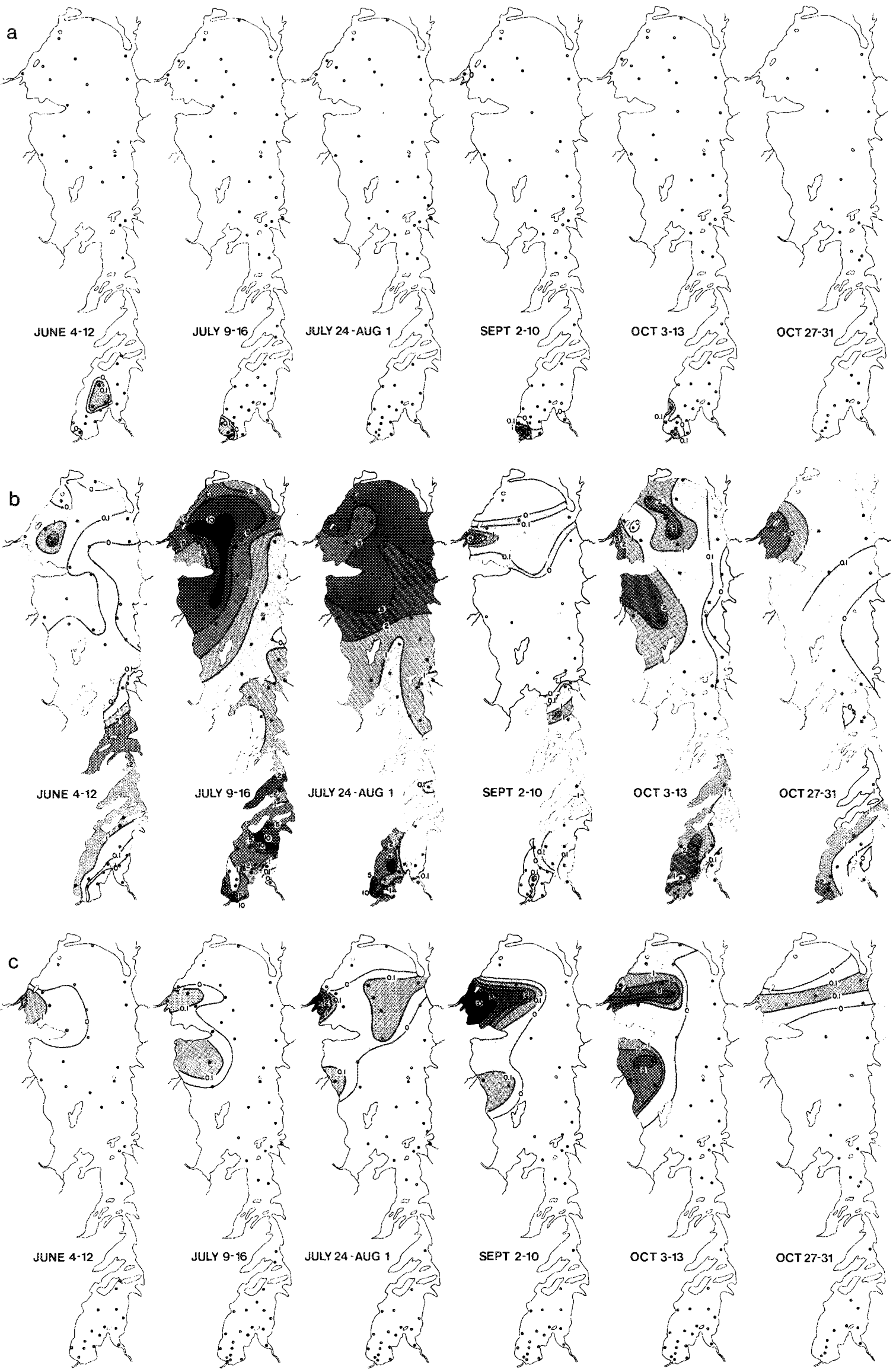

FIG. 12. Spatial distribution of (ind. $\cdot \mathrm{L}^{-1}$ ) of adults and juveniles of (a) Ceriodaphnia quadrangula, (b) Bosmina longirostris, and (c) Chydorus sphaericus in Lake Winnipeg, June-October 1969. 

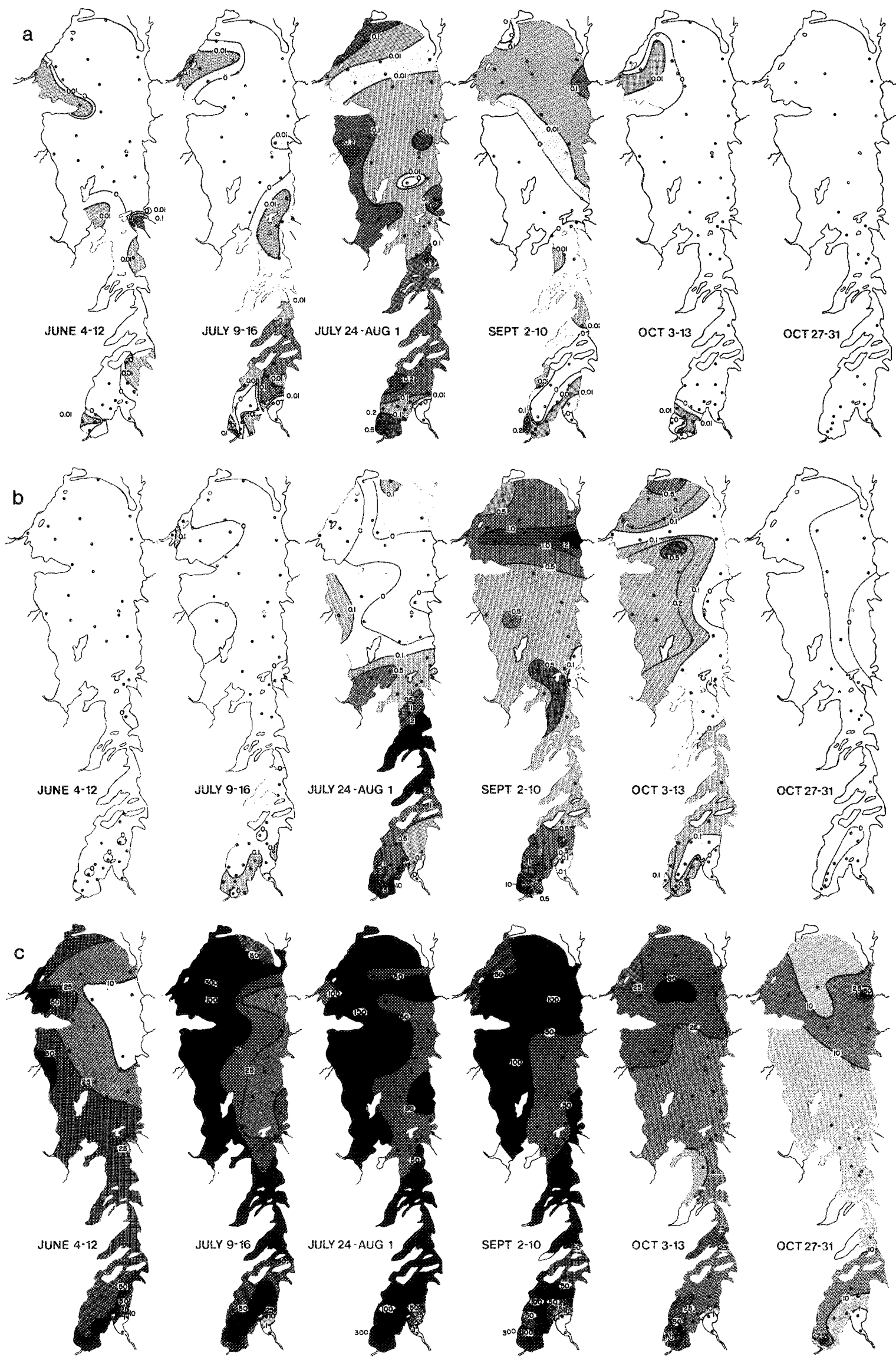

Fig. 13. Spatial distribution of (ind. $\mathrm{L}^{-1}$ ) of adults and juveniles of (a) Leptodora kindtii, (b) Diaphanosoma leuchtenbergianum, and (c) total planktonic crustaceans in Lake Winnipeg, June-October 1969. 


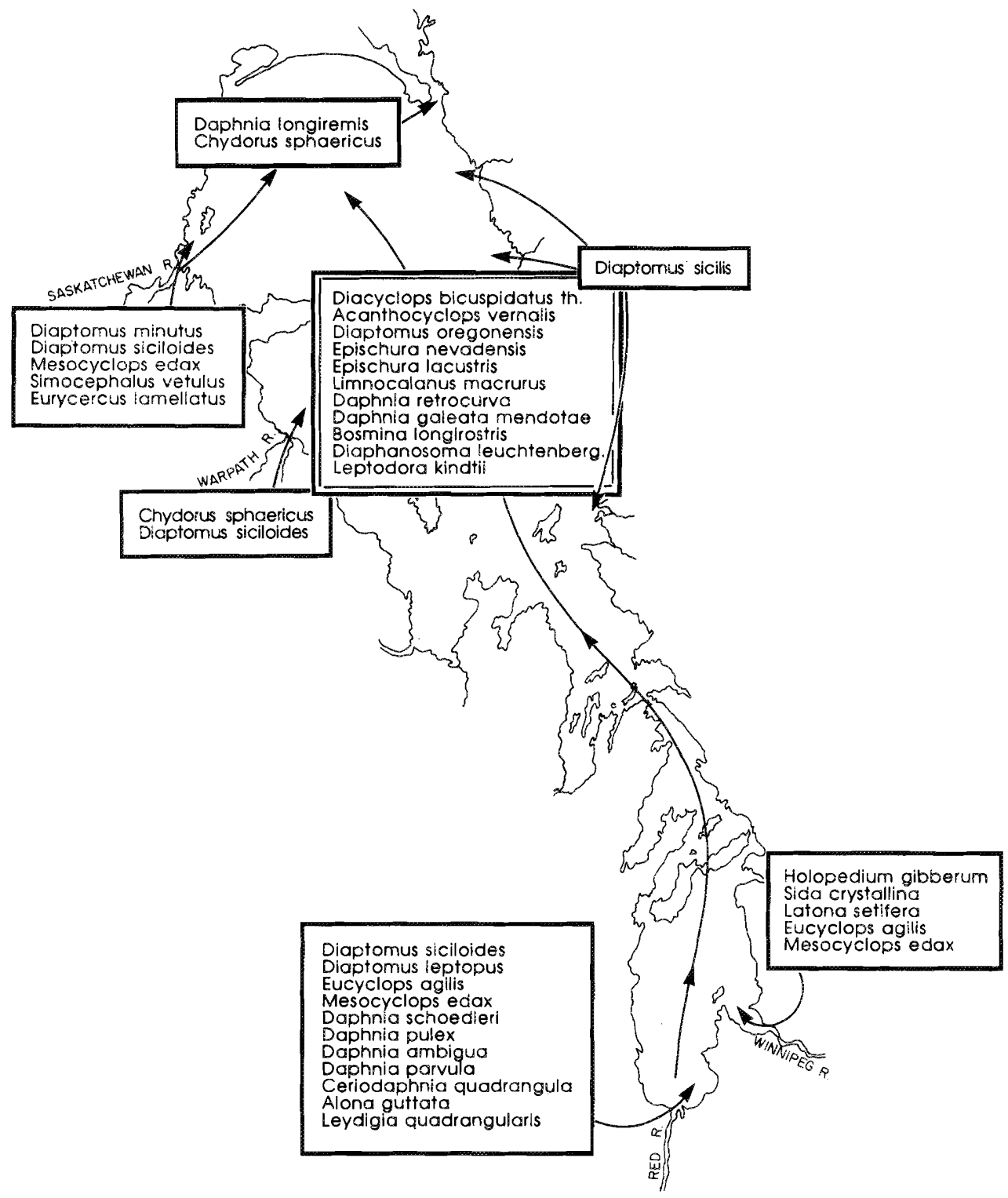

FIG. 14. Schematic diagram of two components of the crustacean community in Lake Winnipeg, "core" species (doubled framed), established all over the lake, and "marginal," unsuccessful invaders (single framed) and their routes of entry.

groups, differences between basins increased substantially. The ratio of cladocerans to calanoids to cyclopoids was $1: 6: 3$ in the South Basin and 1:3:8 in the North Basin, respectively, showing a basically different community structure. Calanoids dominated the South Basin, while cyclopoids did in the North Basin. Cladocerans were less abundant and contributed only 8-10\% to the total abundance of crustaceans in both basins (Fig. 4).

Increasing resolution to the individual species level reveals much larger interbasin differences (Table 3). Only 15 of the 34 species found from June to October were common to both basins. Expressing this ratio in the form of a coefficient of community (Jaccard 1912):

$$
\frac{c}{c+a+b}=0.44
$$

where $a=$ number of species found only in the North Basin (7), $b=$ number of species found only in the South Basin (12), and $c=$ number of species common to both basins.
As Jaccard's coefficient of community is based on the presence or absence of species, it does not reflect the quantitative relationships between the species in the two compared samples. The percentage similarity index (Renkonen 1938)

$$
P i j=\Sigma \operatorname{Min}\{x k i, x k j\}
$$

places emphasis on dominant species and is calculated as the sum of the smaller percentage of each species within a sample pair of $i, j$. This means that in Jaccard's coefficient, every species has the same "weight," and in percentage similarity by Renkonen, the "weight" of the species is proportional to its relative abundance. Both indices range from 0 in two samples without a single common species to 1 where two samples have all the same species, and, as in Renkonen's percentage similarity, those species occur in the same proportions. Within a well-mixed water mass, the distribution of planktonic animals would be expected to be relatively uniform, and both similarity indexes between samples would tend to reach a value of 1.0 . 
Renkonen's percentage similarity index calculated for the North and South basins amounted to a rather low mean value of 0.60 , ranging seasonally from 0.42 to 0.76 . This indicates that not only the overall species composition, as shown by Jaccard's community coefficient, but also the proportions of dominant species varied substantially between the basins. Low similarity shown by both indices reinforces the conclusion about the profound differences existing in the structure of the plankton between the North and South basins.

Spatial variation in plankton composition and abundance existed also within each basin although it was expected to be smaller than between the basins. In order to measure the spatial variance, four regions were defined within each basin. The division was based on the morphology of the lake and the location of the major inflows (Fig. 1). Percentage similarities (Renkonen 1938) were then calculated between all pairs of regions and the results for five consecutive months presented in the form of dendrograms (Fig. 15). A complete linkage agglomerative clustering analysis (Sørensen 1948) was used. In this method, two clusters can fuse only when all objects of the first are linked to all objects of the second (Legendre and Legendre 1983).

The following conclusions are drawn from these dendrograms and the maps of distributions of the individual species (Fig. 6a-13b):

(1) Within the North Basin, the plankton communities of the Saskatchewan River vicinity and the northern part of the North Basin were most similar. Their similarity index was 0.87 on average, ranging from 0.68 to 0.94 during the period from June to October. The eastern part of the North Basin was least similar to the other regions, average similarity with the Saskatchewan River vicinity, the northern part of the North Basin, and the western part of the North Basin being $0.52 ; 0.55$, and 0.66 , respectively.

(2) Within the South Basin, the Red River vicinity and main part of South Basin were the most similar areas at a level averaging 0.80 and ranging from 0.68 to 0.92 . Plankton of the Winnipeg River vicinity was very different from the neighbouring South Basin region, with similarity values not exceeding 0.47 . These values indicate that although the Red River inflow supplies only $20 \%$ of the water, it is rich in plankton and it has a stronger influence on the character of the planktonic communities in the downstream portion of the basin than the Winnipeg River which supplies $80 \%$ of the water (Brunskill et al. 1980) but is extremely poor in plankton. Thus, in spite of a different plankton composition, the Winnipeg River has mainly a diluting effect on the downstream portion of the basin. The geographic proximity of two lake regions, therefore, is not always reflected in a higher similarity of their plankton.

(3) The two pairs of most similar regions (Saskatchewan River vicinity - northern part of the North Basin and Red River vicinity - South Basin) are linked at a rather low level of 0.42 $(0.24-0.66)$ similarity. They are situated at the two extreme north and south ends of the lake, which are subject to differences in climate and fed by different rivers, the Saskatchewan River draining the northern portion of the Saskatchewan prairies with many lakes and reservoirs and the Red River flowing from North Dakota with very few lakes.

(4) Plankton of the Narrows is intermediate in character with an average similarity of 0.68 with both the eastern part of the North Basin and the South Basin. In four of five months, however, it exhibited a tendency to cluster with the South Basin.
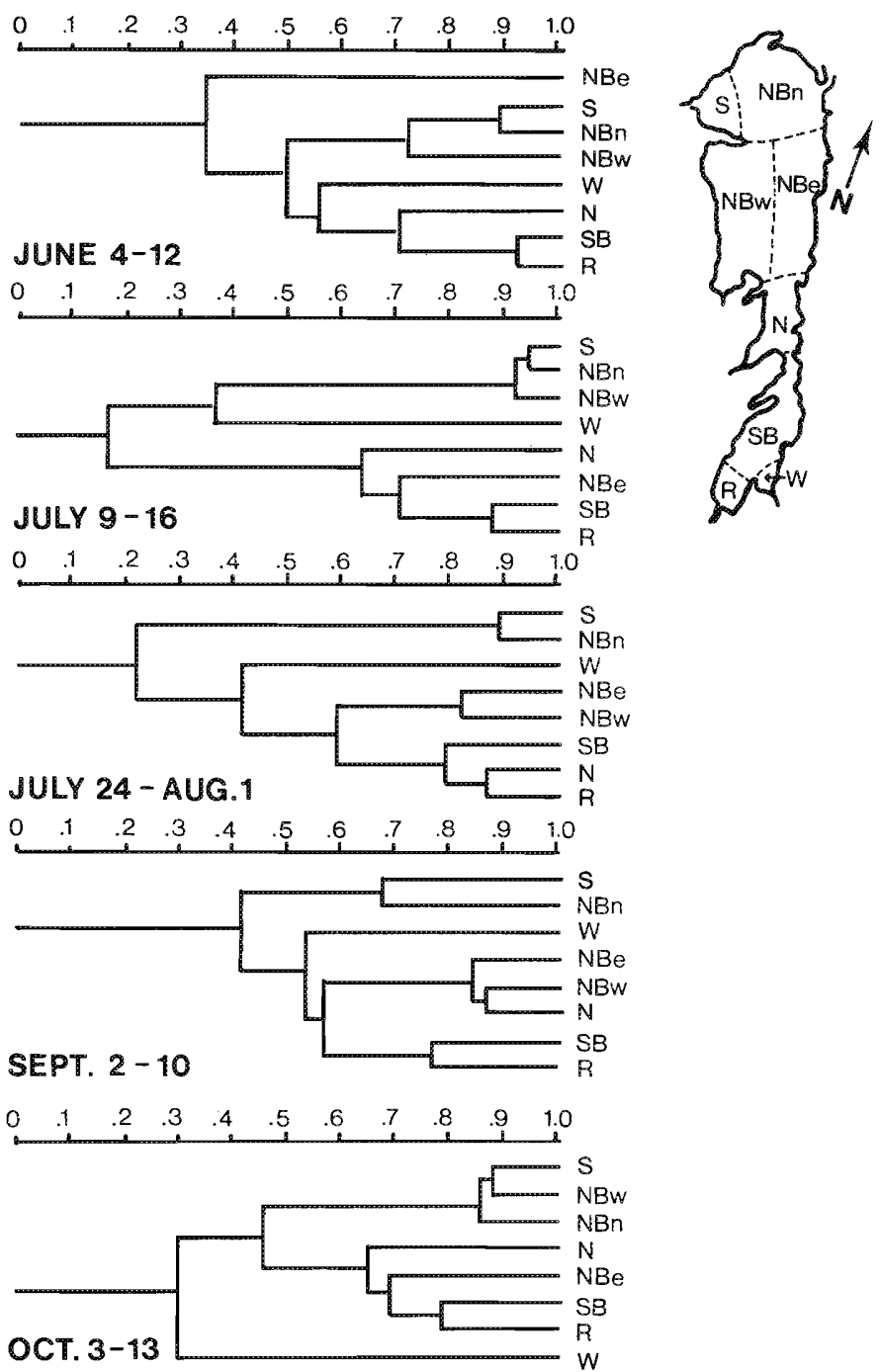

FIG. 15. Seasonal changes in plankton similarity (Renkonen 1938) between various regions of Lake Winnipeg (complete linkage agglomerative clustering; Sørensen 1948) (R, Red River; W, Winnipeg River; SB, main part of the South Basin; N, Narrows; NB, North Basin with subdivisions e (east), w (west), and n (north); S, Saskatchewan River).

(5) The similarity of plankton among the inflow areas of the three major rivers was low. On average, Winnipeg River plankton exhibited similarity indices of only 0.44 and 0.49 with the Saskatchewan and Red rivers, respectively. The Red River inflow area was more similar to the remote Saskatchewan River inflow area $(0.55)$ than to the closely situated Winnipeg River area (0.49). Both the Saskatchewan and Red rivers, although different in character, drain the sedimentary, prairie area, while the Winnipeg River supplies water from the Precambrian Shield.

(6) Plankton in the eastern part of the North Basin was very different from that in other regions in June (similarity 0.33 ). Water temperatures were $2-3^{\circ} \mathrm{C}$ lower than in the remaining parts of the lake (Brunskill et al. 1979a), causing a delay in planktonic development. In July, with more water flowing from the South Basin, the plankton of the eastern part of the North Basin became more similar to that in the South Basin (similarity 0.70 ). In August, September, and October, plankton in all four 


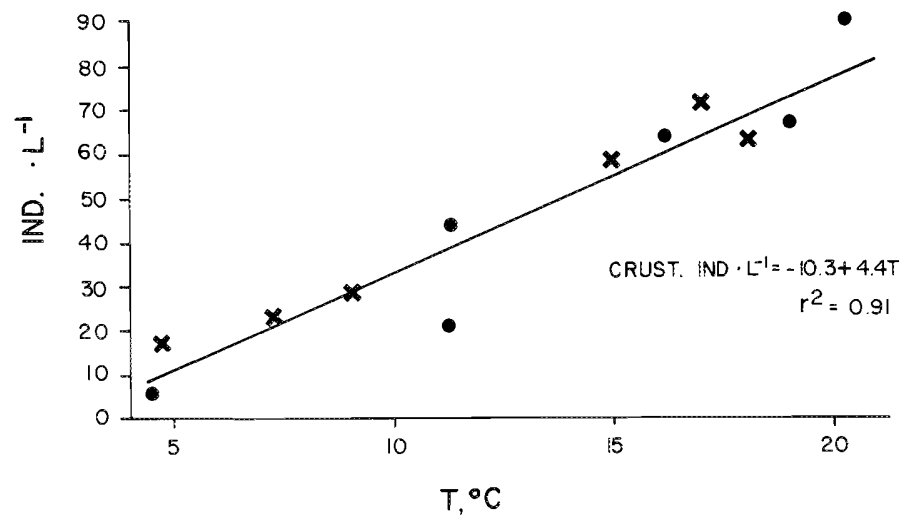

Fig. 16. Relationship between mean total number of planktonic crustaceans and the mean temperature of water in the upper $10-\mathrm{m}$ layer in Lake Winnipeg during June-October 1969. Dots and crosses denote South and North basins, respectively.

regions of the North Basin were more similar to each other than to regions in the South basin.

In general, dendrogram analysis confirmed the higher similarity of plankton between regions within the same basin (usually within the range $0.75-0.95$ ) than between the North and South basins, where the similarity was 0.45 (range $0.24-0.60$ ). Exceptions were regions fed by water from the Precambrian Shield, i.e. the Winnipeg River inflow area in the South Basin and the eastern part of the North Basin.

Water temperature seems to be one of the main factors explaining plankton abundance and its distribution in Lake Winnipeg. On average, water temperatures were $1.77^{\circ} \mathrm{C}$ lower in the North Basin than in the South Basin. If morphometry were responsible for the temperature differences, then the South Basin would be expected to warm up earlier in the spring and cool earlier in the autumn than the deeper, larger North Basin. Instead, in both parts of the lake, water temperatures closely followed air temperatures with a 6- to 12-d lag. The North Basin cooled earlier, indicating that climate was a more important factor than basin morphology.

Seasonal changes in crustacean abundance were also apparently related to water temperature (Fig. 16). Total numbers of crustaceans increased with increasing temperatures, reaching a maximum between late July and early September. Much higher numbers of plankters were found in spring in the warmer South Basin than in the colder North Basin. Cooling of water in October was followed by a decrease in plankton abundance in both the North and South basins. A significant correlation existed between planktonic crustacean abundance and epilimnion temperature (Fig. 16). Such a correlation could not be expected in temperate lakes where spring and autumn maxima are often separated by a midsummer minimum. In Lake Winnipeg, however, there is little indication of seasonal bimodality. Only in the North Basin does some weak indication of such a bimodality exist in chlorophyll concentration (Fig. 5) (see also Hecky et al. 1986). There is a certain minimum response time necessary between a chlorophyll maximum and a succeeding zooplankton peak. Only Cyclopidae nauplii and $B$. longirostris, the two smallest and probably fastest growing categories, responded to the spring and late summer chlorophyll maxima. The remaining species produced rather single-mode patterns, probably because of a shorter ice-free season and the relatively low temperatures prevailing in the lake. Temperatures above $17^{\circ} \mathrm{C}$ do not occur

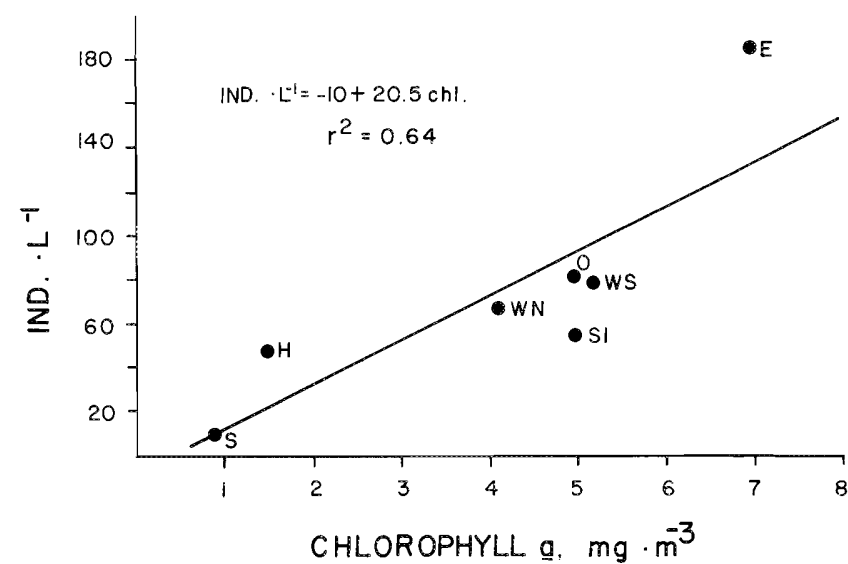

FIG. 17. Relationship between mean crustacean plankton abundance and chlorophyll $a$ concentration in several North American great lakes (E, Lake Erie; O, Lake Ontario; WS, Lake Winnipeg South; WN, Lake Winnipeg North; SI, Southern Indian Lake; H, Lake Huron; S, Lake Superior). Chlorophyll a data from Vollenweider (1976), Brunskill et al. (1979a), Hecky (1975).

for longer than 4-6 wk, and during the remaining period, temperature could be considered as the factor limiting zooplankton growth and reproduction.

Although no correlation was found between chlorophyll $a$ and crustacean abundance, the seasonal pattern of both parameters displayed some similarity (Fig. 5). In the South Basin, maximum concentrations of chlorophyll $a$ were found in midJuly, 2 wk before a maximum of crustacean abundance occurred (G. J. Brunskill, unpubl. data). The September chlorophyll $a$ maximum in the North Basin coincided with the maximum of planktonic crustaceans.

A seasonal succession of species caused by differences in environmental requirements and possibly by interspecific competition was quite apparent in both the South and North basins (Fig. 5). The mid-July peak of D. retrocurva and $B$. longirostris in the South Basin was followed by the late July maximum of $D$. leuchtenbergianum and $L$. kindtii and a September maximum of $D$. galeata mendotae. A similar succession, although delayed by about $2-4 \mathrm{wk}$, was observed in the North Basin. The June maximum of $D$. bicuspidatus thomasi in the South Basin was followed by an A. vernalis maximum in September, with a similar succession, delayed by $1 \mathrm{mo}$, in the North Basin. The Epischura spp. and D. ashlandi late July peaks were succeeded by a $D$. siciloides maximum in September and an October peak of $D$. oregonensis. Delays in population maxima in the North Basin coincided with climaterelated, cooler temperatures in this part of the lake, particularly in late spring and early summer, and also with a delayed chlorophyll a maximum (Fig. 5).

The average number of planktonic crustaceans in midsummer samples from the South and North basins amounted to 90 and 63 ind. $\cdot \mathrm{L}^{-1}$, respectively. These figures are relatively high when compared with other great lake plankton densities (Patalas 1975). Lake Winnipeg plankton abundances of 63-90 ind. $\mathrm{L}^{-1}$ fall into the upper middle portion of the range for North American great lakes (Table 4). Only Lake Erie had more crustaceans per litre than Lake Winnipeg. No significant correlation was found between crustacean abundance, mean depth, and Secchi disc transparency. However, as demonstrated (Patalas 1975), in such a wide range of lakes, crustacean abun- 
TABLE 4. Midsummer abundance of crustaceans and some limnological characteristics of several North American great lakes. (Midsummer values of the whole water column or $0-50 \mathrm{~m}$ in deeper lakes. Standard errors in parentheses. The limnological characteristics are based mostly on Rawson (1960), Chandler (1964), Brunskill et al. (1979a, 1979b, 1980), Patalas and Patalas (1978), Patalas (1969), and on the data from the Canada Centre for Inland Waters (Anonymous 1970a, 1970b, 1970c). Wellseparated basins of Lake Erie, Lake Winnipeg, and Great Slave Lake were treated here as distinct water bodies.

\begin{tabular}{lcccc}
\hline \hline \multicolumn{1}{c}{ Lake } & $\begin{array}{c}\text { Mean depth } \\
(\mathrm{m})\end{array}$ & $\begin{array}{c}\text { Secchi } \\
(\mathrm{m})\end{array}$ & $\begin{array}{c}\text { Epilimnion } \\
\text { temperature } \\
\text { mean }\left({ }^{\circ} \mathrm{C}\right)\end{array}$ & $\begin{array}{c}\text { Crustaceans } \\
\left(\text { ind. } \cdot \mathrm{L}^{-1}\right)\end{array}$ \\
\hline Erie Central & 18 & $2.9(0.25)$ & $21.7(0.30)$ & $184(26.8)$ \\
Erie East & 24 & $3.6(0.41)$ & $21.0(0.50)$ & $154(27.1)$ \\
Erie West & 8 & 2.0 & $23.5(0.10)$ & $128(12.8)$ \\
Ontario & 86 & $3.2(0.16)$ & $18.5(0.60)$ & $80(10.4)$ \\
Winnipeg South & 9 & 0.8 & $20.3(0.22)$ & $90(16.3)$ \\
Winnipeg North & 12 & 1.9 & $18.5(0.19)$ & $63(5.7)$ \\
South Indian & 9 & $2.0(0.09)$ & $17.5(0.13)$ & $54(5.4)$ \\
Reindeer & 17 & $7.0(0.21)$ & $14.2(0.11)$ & $50(3.2)$ \\
Huron & 59 & $7.1(0.29)$ & $17.6(0.40)$ & $48(5.1)$ \\
La Martre & 11 & 6.0 & $12.8(0.22)$ & $21(2.2)$ \\
Superior & 148 & $7.9(0.27)$ & $9.5(0.38)$ & $10(0.9)$ \\
Great Slave West & 41 & $2.5(0.30)$ & $10.0(0.62)$ & $3(0.3)$ \\
Great Slave East & 185 & $9.0(0.60)$ & $4.0(0.40)$ & $3(0.3)$ \\
Great Bear & .76 & 20.0 & 4.0 & 1 \\
\hline
\end{tabular}

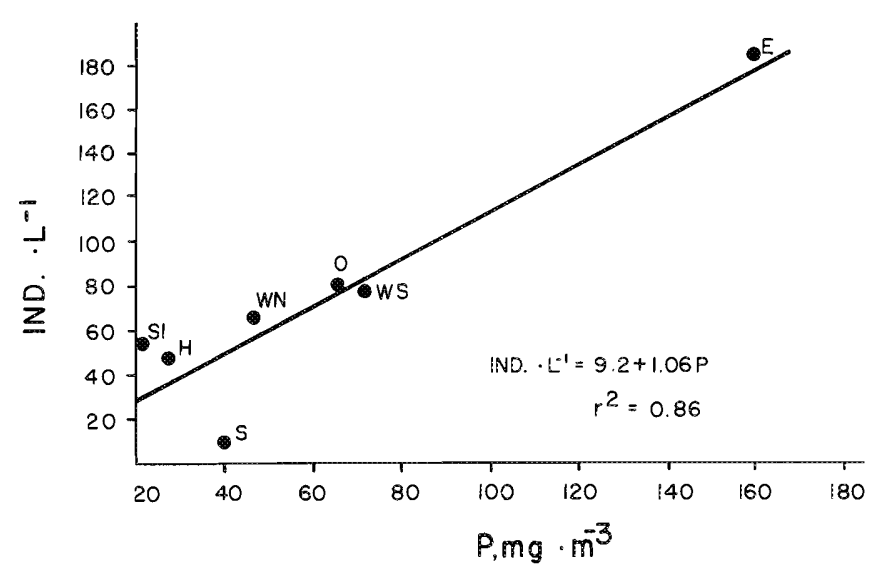

FIG. 18. Relationship between mean crustacean plankton abundance and mean concentration of total phosphorus in inflowing waters $(E$, Lake Erie; O, Lake Ontario; WS, Lake Winnipeg South; WN, Lake Winnipeg North; SI, Southern Indian Lake; H, Lake Huron; S, Lake Superior). Phosphorus data from Vollenweider (1976), Brunskill (1974), and Hecky (1975).

dance was significantly correlated with midsummer epilimnion temperature $\left(r^{2}=0.92 ; p<0.01\right)$. The correlation with chlorophyll $a$ concentration (Fig. 17) was significant but only barely so $\left(r^{2}=0.64 ; p=0.05\right)$.

A good correlation $\left(r^{2}=0.86 ; p<0.01\right)$ existed between midsummer crustacean density and annual mean total phosphorus concentration in inflowing water (Fig. 18). Only very cold Lake Superior revealed crustacean numbers lower than predicted from the regression. A multiple regression with epilimnion temperature and phosphorus concentration in inflowing water used as independent variables (Fig. 19) gave a much better correlation $\left(r^{2}=0.97 ; p<0.01\right)$.

Crustacean densities observed in the North Basin of Lake Winnipeg were very close to those expected. Values in the South Basin, about $20 \%$ lower than predicted, may have been influenced by apparent light limitation (Brunskill et al. 1979b; Healey and Hendzel 1980) which prevented full utilization of

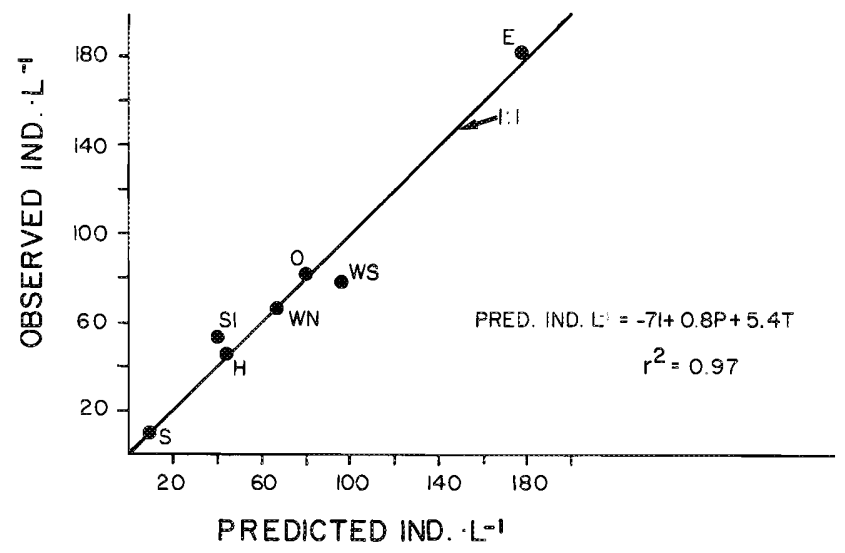

FrG. 19. Planktonic crustacean abundance observed and predicted from the mean concentration of total phosphorus in the inflowing waters and epilimnion temperature in summer (E, Lake Erie; O, Lake Ontario; WS, Lake Winnipeg South; WN, Lake Winnipeg North; SI, Southern Indian Lake; H, Lake Huron; S, Lake Superior).

available nutrients for algal production. As indirect evidence, the average concentration of chlorophyll $a, 5.3 \mathrm{mg} \cdot \mathrm{m}^{-3}$, observed in the South Basin is much lower than the $14.8 \mathrm{mg} \cdot \mathrm{m}^{-3}$ predicted from phosphorus inflow concentration $(\mathrm{Pi})$ and water renewal time $(t)$ using Vollenweider's (1976) formula:

$$
\begin{aligned}
& \text { Chlorophyll } a=0.35 \mathrm{Pi} \cdot \frac{1}{1+\sqrt{t}}, \\
& \qquad \mathrm{Pi}=72 \mathrm{mg} \cdot \mathrm{m}^{-3} \text { and } t=0.5 \mathrm{yr} .
\end{aligned}
$$

Has the plankton of Lake Winnipeg changed in response to cultural eutrophication within its drainage basin? One of the earliest and most complete studies of plankton composition and abundance in Lake Winnipeg was conducted by Bajkov (1930, 1934). Of the 34 species recorded in the present study, 19 were previously recorded by Bajkov (Table 5). Sixteen littoral and benthic species listed by Bajkov were not recorded in 1969 mainly due to the pelagic nature of sampling sites in this study. 
TABLE 5. List of species found in Lake Winnipeg in 1929 as recorded by Bajkov (1934) and in 1969 by the present authors.

\begin{tabular}{|c|c|}
\hline 1929 & 1969 \\
\hline $\begin{array}{l}\text { Limnocalanus macrurus Sars } \\
\text { Epischura lacustris Forbes }\end{array}$ & $\begin{array}{l}\text { Limnocalanus macrurus Sars } \\
\text { Epischura lacustris } \text { Forbes }\end{array}$ \\
\hline Diaptomus ashlandi Marsh & Epischura nevadensis Lilljeb. \\
\hline Diaptomus sicilis Forbes & Diaptomus oregonensis Lilljeb. \\
\hline Diaptomus leptopus Forbes & Diaptomus sicilis Forbes \\
\hline & Diaptomus siciloides Lilljeb. \\
\hline Cyclons viridis Jurine & $\begin{array}{l}\text { Diaptomus minutus Lilljeb. } \\
\text { Diaptomus leptopus Forbes }\end{array}$ \\
\hline $\begin{array}{l}\text { Cyclops virldis Junne } \\
\text { Cyclops prasinus Fischer } \\
\text { Cyclops phaleratus Koch } \\
\text { Cyclops serrulatus Fischer }\end{array}$ & $\begin{array}{l}\text { Diaptomus clavipes Schacht } \\
\text { Diacyclops bicuspidatus thom. Forbes } \\
\text { Acanthocyclops vernalis (Fischer) }\end{array}$ \\
\hline $\begin{array}{l}\text { Cyclops fimbriatus Fischer } \\
\text { Daphnia retrocurva Forbes } \\
\text { Daphnia longispina Mueller } \\
\text { Daphnia longispina hyalina Leydig }\end{array}$ & $\begin{array}{l}\text { Eucyclops agilis (Koch) } \\
\text { Mesocyclops edax (Forbes) } \\
\text { Macrocyclops albidus (Jurine) } \\
\text { Daphnia retrocurva Forbes }\end{array}$ \\
\hline Daphnia pulex de Geer & $\begin{array}{l}\text { Daphnia galeata mendotae Birge } \\
\text { Daphnia pulex Leydig }\end{array}$ \\
\hline Ceriodaphnia pulchella Sars & Daphnia schoedleri Sars \\
\hline $\begin{array}{l}\text { Simocephalus vetulus Mueller } \\
\text { Simocephalus serrulatus Koch } \\
\text { Moina rectirostris (Leydig) }\end{array}$ & $\begin{array}{l}\text { Daphnia longiremis Sars } \\
\text { Daphnia parvula Fordyce } \\
\text { Daphnia ambigua Scourfield }\end{array}$ \\
\hline $\begin{array}{l}\text { Bosmina longirostris (Mueller) } \\
\text { Bosmina longispina Leydig }\end{array}$ & $\begin{array}{l}\text { Ceriodaphnia quadrangula (Mueller) } \\
\text { Simocephalus vetulus Schoedler }\end{array}$ \\
\hline $\begin{array}{l}\text { Chydorus sphaericus (Mueller) } \\
\text { Chydorus gibbus Lilljeb. }\end{array}$ & Bosmina longirostris (Mueller) \\
\hline Alona affinis Leydig & Chydorus sphaericus (Mueller) \\
\hline Alona costata Sars & Alona guttata Sars \\
\hline $\begin{array}{l}\text { Pleuroxus procurvatus Birge } \\
\text { Pleuroxus denticulatus Birge }\end{array}$ & $\begin{array}{l}\text { Alona quadrangularis (Mueller) } \\
\text { Leydigia quadrangularis (Leydig) }\end{array}$ \\
\hline Kurzia latissima (Kurz) & Latona setifera (Mueller) \\
\hline & $\begin{array}{l}\text { Eurycercus lamellatus (Mueller) } \\
\text { Holopedium gibberum Zaddach }\end{array}$ \\
\hline $\begin{array}{l}\text { Diaphanosoma leuchtenbergianum (Fisch.) } \\
\text { Sida crystallina (Mueller) } \\
\text { Leptodora kindtii (Focke) }\end{array}$ & $\begin{array}{l}\text { Diaphanosoma leuchtenbergianum (Fischer) } \\
\text { Sida crystallina (Mueller) } \\
\text { Leptodora kindtii (Focke) }\end{array}$ \\
\hline
\end{tabular}

The remaining 15 species, not recorded by Bajkov, mostly very rare, were found in the present study only in restricted areas. Species more widely distributed in 1969 but not mentioned by Bajkov are E. nevadensis, D. oregonensis, D. siciloides, $A$. vernalis, and $D$. longiremis.

Epischura nevadensis is difficult to distinguish from E. lacustris even in late copepodid stages. Cyclops viridis listed by Bajkov is probably $A$. vernalis. Yeatman (1959) mentioned that most specimens recorded as $C$. viridis are really other species, mainly $A$. vernalis. Changes in taxonomy could certainly explain the discrepancies between Bajkov's Daphnia list and that of the present authors (Brooks 1957; Wilson 1959).

Thus, it is unlikely that any of the planktonic species recorded by Bajkov in 1929 (Bajkov 1934) disappeared from the lake by 1969. The increased number of species recorded in the 1969 samples is probably due to the increased intensity of sampling and to some extent to the taxonomy applied. By applying the settling procedure described in Bajkov (1930), a comparison of the settled net plankton volumes (including both phyto- and zooplankton) in 1929 and 1969 was possible. Lake Winnipeg settled net plankton volumes during the 1929 season were significantly below 1969 values except for mid-August data when the density was $20.2 \mathrm{~mm}^{3} \cdot \mathrm{L}^{-1}$, about five times that of the other summer months. Unfortunately, no sampling was done on a comparable date in August 1969 during the 5-wk interval from July 27 to September 4, and an algal bloom could have been missed. In spite of this, the 1969 seasonal average settled net plankton volume was almost double that in 1929, 9.2 and $5.8 \mathrm{~mm}^{3} \cdot \mathrm{L}^{-1}$, respectively. When the August 1929 extreme peak is excluded, the average 1969 net plankton is three times greater than in $1929,9.2$ and $3.0 \mathrm{~mm}^{3} \cdot \mathrm{L}^{-1}$, respectively.

Secchi disc transparency can be another indication of changing conditions, but because it varies with season and location, it would be difficult to document statistically significant changes between 1929 and 1969. However, cautious examination of the existing data suggests that some significant changes may have occurred in the lake during this $40-y r$ period. Bajkov (1930) recorded 1.5-m Secchi disc transparency in the middle of the South Basin in 1929. The corresponding 1969 average measurement at stations 57 and 59 from July until September was $0.74 \mathrm{~m}$, with a range of $0.5-1.0 \mathrm{~m}$. The North Basin exhibited a reversed trend with a Secchi depth of $1.6 \mathrm{~m}$ in 1929 and $2.2 \mathrm{~m}$ in 1969. Also, near the mouth of the Saskatchewan River, a transparency of only $0.1 \mathrm{~m}$ was recorded in 1929 , but as much as $2.1 \mathrm{~m}$ (range $1.2-3.0 \mathrm{~m}$ ) was found, on average, between July and September 1969 (Brunskill et al. 
TABLE 6. Monthly mean air temperatures in the summers of 1929 and 1969 (Transport Canada, Meteorological Branch).

\begin{tabular}{lllc}
\hline & \multicolumn{2}{c}{ Temp. $\left({ }^{\circ} \mathrm{C}\right)$} & \\
\cline { 2 - 3 } Month & 1929 & 1969 & $\begin{array}{c}\text { Difference between } \\
1929 \text { and } 1969\left({ }^{\circ} \mathrm{C}\right)\end{array}$ \\
\hline June & 17.0 & 12.2 & +4.8 \\
July & 20.1 & 18.5 & +1.1 \\
August & 20.2 & 20.9 & -0.7 \\
Mean & 19.1 & 17.2 & +1.9 \\
\hline
\end{tabular}

1979a). The latter values have also been confirmed by Derksen and Hangasjarvi (1979) who recorded $2.4 \mathrm{~m}$ on average, with a range of $1.5-3.0 \mathrm{~m}$, in July 1974 in the same area. Not a single 1969 measurement was close to the $0.1-\mathrm{m}$ Secchi depth measured in 1929. The higher North Basin transparencies in 1969 could be explained by the Cedar Lake - Grand Rapids impoundment completed in about 1964. This new reservoir could act as a sediment and nutrient trap for the Saskatchewan River. On the other hand, nutrient loading rates to the South Basin have probably increased since 1929 . Although there was a lack of direct measurement in 1929, some extrapolation can be made from later (Brunskill 1974; Brunskill et al. 1980) estimates. According to these authors, the 1970-74 loading of total phosphorus, expressed as the annual mean concentration in water flowing into the South Basin of Lake Winnipeg, was $97 \mathrm{mg} \cdot \mathrm{m}^{-3}$.

A hypothetical phosphorus loading for 1929 can be backcalculated using the following assumptions: (1) the human and livestock population in 1929 amounted to $0.6-0.7$ of 1970 levels, (2) the use of fertilizers in 1929 was not greater than 0.05 of the 1970 level, and (3) the anthropogenic input in 1970 was 0.7 of the total phosphorus loading.

The 1929 total phosphorus loading estimate, based on these assumptions, was $50 \mathrm{mg} \cdot \mathrm{m}^{-3}$, i.e. about half the 1970 level. Similarly, during the period from 1929 and 1969 the net plankton settled volume in Lake Winnipeg doubled. The average Secchi disc transparency of water in the South Basin decreased from 1.5 to $0.75 \mathrm{~m}$ but increased in the North Basin, probably due to the sediment and nutrient trapping effect in Cedar Lake.

It is difficult to conclude with certainty whether these differences represent normal, climate-related, year-to-year variation rather than effects of increased nutrient loading. Comparison of the climatic conditions in these two years (Table 6) indicates that two of three months in the summer of 1929 were warmer than in 1969 , and the corresponding mean temperatures were on average $1.9^{\circ} \mathrm{C}$ higher than in 1969 . Plankton abundance usually increases with temperature in lakes of the temperate zone (Fig. 16; see also Patalas 1975). With nutrient loading constant, greater amounts of plankton are observed in warmer summers. Thus, in Lake Winnipeg, because more plankton was found in 1969 in spite of the cooler summer, the increased abundance of plankton appears to be a function of increased nutrient loading.

Most of the conclusions in this paper could not have been reached without the application of maps of distribution of individual species. These maps allowed an analysis of invasion routes and changes in the distribution in consecutive months indicating rates and directions of expansion. This analysis of individual species behaviour sheds some light on the formation and dynamics of the planktonic community in an aquatic system as large and complex as Lake Winnipeg. Also, it helped us to understand the response of planktonic community structure to abiotic factors in the ecosystem. Patterns as complex as those in Lake Winnipeg were also observed in other North American great lakes although the causes of such a complexity may differ in each individual case (Patalas 1990).

This study demonstrated that lake morphology, the location of major river inflows, the geology of the drainage basin, and the climatic differences within the system sufficiently explained most of observed patterns of distribution of planktonic crustaceans.

\section{Acknowledgments}

We are indebted to Dr. G. J. Brunskill and Dr. D. Malley for a valuable criticism of the manuscript. We thank also the crew members of the cruises who put much effort into collecting the valuable samples.

\section{References}

ANONYMOUS. 1929-68. Monthly records, meteorological observations in Canada. Canada Department of Transport, Meteorological Branch, Ottawa, Ont.

1970a. Lake Ontario. Limnological Data Report Nos. 1 and 2, 1967. Canadian Oceanographic Data Centre, Canada Centre for Inland Waters, Burlington, Ont. 179 and $212 \mathrm{p}$.

1970b. Lake Erie. Limnological Data Report No. 1, 1968. Canada Oceanographic Data Centre, Canada Centre for Inland Waters, Burlington, Ont. $131 \mathrm{p}$.

1970c. Lake Huron, Lake Superior. Limnological Data Report No. 1, 1968. Canadian Oceanographic Data Centre, Canada Center for Inland Waters, Burlington, Ont. 131 p.

BAJKOV, A. 1930. Biological conditions of Manitoba lakes. Contrib. Can. Biol. Fish. 5(12): 383-422.

1934. The plankton of Lake Winnipeg drainage system. Int. Rev. Gesamten Hydrobiol. Hydrogr. 31: 239-272.

Brooks, J. L. 1957. The systematics of North American Daphnia. Mem. Conn. Acad. Arts Sci. 13: 1-180.

BRUNSKILL, G. J. 1974. Rates of supply of nitrogen and phosphorus to Lake Winnipeg, Manitoba, in relation to the diversion of Missouri River into the Red and Assiniboine rivers in Manitoba, p. D1-15. In W. G. Leitch and J. J. Keleher [ed.] Garrison Diversion Project presentation. Manitoba Environmental Council, Study 2.

BRUnSKill, G. J., P. CAMPBell, AND S. E. M. Elliot. 1979a. Temperature, oxygen, conductance and dissolved major elements in Lake Winnipeg. Can. Fish. Mar. Serv. MS Rep. 1526: v + 127 p.

Brunskill, G. J., S. E. M. Elliot, and P. CAMPBEll. 1980. Morphometry, hydrology, and watershed data pertinent to the limnology of Lake Winnipeg. Can. MS Rep. Fish. Aquat. Sci. 1556: v + 23 p.

Brunskill, G. J., D. W. Schindler, S. E. W. Elliot, and P. CAMPBell. 1979b. The attenuation of light in Lake Winnipeg waters. Can. Fish. Mar. Serv. MS Rep. 1522: v +79.

ChandleR, D. C. 1964. The St. Lawrence Great Lakes. Verh. Int. Ver. Limnol. 15: 59-75.

Derksen, A. J., AND E. I. Hangasjarvi. 1979. A survey of net plankton in the North Basin of Lake Winnipeg, July, 1974. Man. Dep. Mines Nat. Resour. Environ. MS Rep. 79-46.

Healey, F. P., AND L. L. HeNDZel. 1980. Physiological indicators of nutrient deficiency in lake plankton. Can. J. Fish. Aquat. Sci. 37: 442-453.

HECKY, R. E. 1975. The phytoplankton and primary productivity of Southern Indian Lake (Manitoba), a high latitude, riverine lake. Verh. Int. Ver. Limnol. 19: 599-605.

HECKY, R. E., H. J. KLING, AND G. J. BRUNSKILL. 1986. Seasonality of phytoplankton in relation to silicon cycling and interstitial water circulation in large, shallow lakes of central Canada. Hydrobiologia 138: 117-126.

JACCARD, P. 1912. The distribution of the flora in the alpine zone. New Phytol. 11: $37-50$.

LEGENDRE, L., AND P. LegendRE. 1983. Numerical ecology. Elsevier Scientific Publishing Company, Amsterdam, The Netherlands. 419 p.

Patalas, J., AND K. Patalas. 1978. Spatial variation in size and reproductive cycle of Limnocalanus macrurus in a deep, subarctic lake, Great Slave Lake. Verh. Int. Ver. Limnol. 20: 150-158.

Patalas, K. 1969. Composition and horizontal distribution of crustacean plankton in Lake Ontario. J. Fish. Res. Board Can. 26: 2135-2164.

1972. Crustacean plankton and eutrophication of St. Lawrence Great 
Lakes. J. Fish. Res. Board Can. 29: 1451-1462.

1975. The crustacean plankton communities of fourteen North American great lakes. Verh. Int. Ver. Limnol. 19: 504-511.

1981. Spatial structure of the crustacean planktonic community in Lake Winnipeg, Canada. Verh. Int. Ver. Limnol. 21: 305-311.

1990. Patterns in zooplankton distribution and their causes in North American great lakes, p. 440-458. In M. M. Tilzer and C. Serruya [ed.] Large lakes ecological structure and function. Springer-Verlag, Berlin.

RAWSON, D. S. 1960. A limnological comparison of twelve large lakes in northern Saskatchewan. Limnol. Oceanogr. 5: 195-211.

RENKONEN, O. 1938. Statistisch- oekologische Untersuchungen ueber die terrestrische Kaeferwelt der finnischen Bruchmoore. Ann. Zool. Soc. Zool. Bot. Fenn. Vanamo 6: 1-231.
SAlkI, A., AND K. Patalas. 1992. Crustacean plankton of Lake Winnipeg, June to October, 1968. Can. Data Rep. Fish. Aquat. Sci. 868: iv +16 p. SøRENSEN, T. 1948. A method of establishing groups of equal amplitude in plant sociology based on similarity of species content and its application to analysis of the vegetation on Danish commons. Biol. Skr. 5: 1-34.

VOLLENWEIDER, R. A. 1976. Advances in defining critical loading levels for phosphorus in lake eutrophication. Mem. Ist. Ital. Hydrobiol. 33: 53-83.

WILSON, M. S. 1959. Calanoida, p. 738-794. In W. T. Edmondson [ed.] Ward and Whipple. Fresh-water biology. Wiley and Sons, New York, NY.

Yeatman, H. C. 1959. Cyclopoida, p. 795-815. In W. T. Edmondson [ed.] Ward and Whipple. Fresh-water biology. John Wiley and Sons, New York, NY. 